\title{
25 Research Soure \\ Pre-clinical validation of a novel pan-cancer CAR-T cell immunotherapy against nfP2X7
}

\section{Veronika Bandara}

University of Adelaide

Jade Foeng

University of Adelaide https://orcid.org/0000-0002-4433-4577

\section{Batjargal Gundsambuu}

Robinson Research Institute, University of Adelaide

\section{Todd Norton}

University of Adelaide

\section{Silvana Napoli}

University of Adeliade

Dylan McPeake

University of Adeliade

Timona Tyllis

University of Adeliade

\section{Elaheh Rohani Rad}

University of Adeliade

Caitlin Abbott

University of Adeliade

\section{Stuart Mills}

University of South Australia

\section{Lih Tan}

Centre for Cancer Biology, University of South Australia

\section{Vasiliki Willet}

University of Adelaide

\section{Victoria Nikitaras}

University of Adelaide

\section{Adam Johnson}

Seattle Children's Research Institute

Justin Coombs

Carina Biotech

Martin Oehler

Royal Adelaide Hospital

Carmela Ricciardelli 
University of Adelaide

\section{Allison Cowin}

University of South Australia https://orcid.org/0000-0003-2885-2080

\section{Claudine Bonder}

Centre for Cancer Biology https://orcid.org/0000-0001-9875-967X

\section{Michael Jensen}

Seattle Children\&\#39;s Research Institute https://orcid.org/0000-0001-7477-3063

\section{Timothy Sadlon}

Robinson Research institute https://orcid.org/0000-0002-4821-2462

\section{Shaun McColl}

University of Adelaide

simon barry ( $\square$ simon.barry@adelaide.edu.au )

University of Adelaide

\section{Article}

Keywords: Chimeric antigen receptor (CAR)-T immunotherapy, CAR-T cells, nfP2X7

Posted Date: December 1st, 2021

DOI: https://doi.org/10.21203/rs.3.rs-1073214/v1

License: (c) (i) This work is licensed under a Creative Commons Attribution 4.0 International License. Read Full License 


\section{Abstract}

Chimeric antigen receptor (CAR)-T immunotherapy is a novel treatment that genetically modifies the patient's own T cells to target and kill malignant cells. CAR-T cells demonstrated robust clinical activity against certain B-cell malignancies. However, identification of tumour-specific antigens expressed on multiple cancer types, especially on solid cancers, remains a major challenge. P2X purinoceptor 7 (P2X7) is an ATP gated cation channel that forms homotrimers and heterotrimers at the cell surface. When functioning normally, it controls ion transport in response to ATP. A dysfunctional version of P2X7, named nfP2X7, has been identified on cancer cells from a range of tissues, while being undetectable on healthy cells. We generated prototype nfP2X7-targeting human CAR-T cells, which demonstrated effective antigen-specific cytotoxicity against twelve solid cancer types including breast, prostate, lung, colorectal, brain and skin in vitro. In preclinical xenograft mouse models of aggressive breast and prostate cancer, CAR-T cells targeting nfP2X7 exhibited robust anti-tumour efficacy. These data indicate CAR-T cells targeting nfP2X7 have potential as a novel broad-spectrum cancer immunotherapy for solid tumours in humans.

\section{Introduction}

Immunotherapy - enabling a cancer patients' own immune cells to recognize and attack their tumours, represents a paradigm shift in the treatment of cancer. This shift is towards a personalised treatment that does not require broad therapies such as chemotherapy to achieve clinical endpoints. These immunotherapies arm immune cells to specifically recognise and destroy malignant cells, which requires tight regulation to prevent collalateral damage to healthy tissues. One immunotherapy approach showing much promise is Chimeric Antigen Receptor (CAR)-T cell therapy, which combines the antigen-specific binding properties of monoclonal antibodies with the killing and self-renewal capacity of $T$ cells. The elegant simplicity of the CAR-T cell platform is that it combines the ability to target unprocessed antigens using antibody-like binding domains in an MHC-independent manner with the intracellular signalling required to initiate cytotoxic activity in T cells. Recent clinical trials of CD19-targeting CAR-T cell therapy have demonstrated impressive results in treating a variety of haematological malignancies, with complete remission rates of up to $80-93 \%$ in patients with relapsed or refractory B-cell acute lymphoblastic leukaemia (B-ALL) (Maude et al., 2018, Turtle et al., 2016) and long-term remission of 20 months in adult patients with a low disease burden of relapsed B-ALL (Park et al., 2018). CD19-targeting CAR-T cell therapy has also achieved significant clinical responses in patients with chronic lymphocytic leukemia (CLL) and non-Hodgkin's lymphoma (Kochenderfer et al., 2010, Brentjens et al., 2011, Porter et al., 2015, Porter et al., 2011).

Robust CAR-T cell clinical activity against these haematological cancers has inspired the search for tumour specific antigens, which will enable the generation of CAR-T cells capable of attacking a broad range of other cancers, especially solid tumours. However, clinical trials with CAR-T cell therapies against solid tumours have yielded disappointing results, as demonstrated by a meta-analysis of CAR-T cell therapy against solid tumours that revealed a 9\% overall response rate across 22 clinical trials (Hou et al., 
2019). The limited response of CAR-T cell therapies towards solid tumours in clinical trials may be due to a number of factors, including the quality of the CAR-T cells, inefficient homing of CAR-T cells and immunosuppression within the tumour microenvironment. Tumour heterogeneity is frequently observed in solid cancers, and is another issue that may hinder CAR-T cell therapy, causing tumour escape and patient relapse (Dagogo-Jack and Shaw, 2018). In addition, the selection of target antigens which are only found on the malignant cells is challenging. While administration of CD19-targeting CAR-T cell therapy results in the elimination of both healthy and malignant B cells, causing B cell hypoplasia, this on-target off-cancer cytotoxicity can be clinically managed. Of the limited selection of antigens expressed by solid cancers investigated to date, many are either also present on healthy cells in a variety of tissues, risking on-target off-cancer cytotoxicity and organ damage, or are present in only a small number of cancers. To avoid these serious adverse effects due to on-target off-tumour cytotoxicity or restricted application, it is critical to find and validate CAR-T targets that are absent on healthy cells, and preferably are expressed by a wide range of solid tumours.

P2X purinoceptor 7 (P2X7) is an ATP-gated cation channel which is widely expressed on many tissues and on haematopoetic cells (Surprenant et al., 1996, Lara et al., 2020). When functioning normally, P2X7 controls ion transport in response to ATP, in which short-term ATP binding results in the opening of the cation-selective channel to allow $\mathrm{Na}^{+}$and $\mathrm{Ca}^{2+}$ influx and $\mathrm{K}^{+}$efflux. This drives downstream signalling pathways involved in cytokine relase, cell survival and proliferation. Under prolonged binding to ATP in ATP-rich conditions, P2X7 functions as a non-selective pore and becomes permeable to large molecules ( $<900 \mathrm{Da}$ ),which results in programmed cell death (Gilbert et al., 2019, Savio et al., 2018). This results in a dichotomous response in that activity of the cation channel can promote either survival or death of the cell.

Several studies have characterised a non-functional version of P2X7, named nfP2X7. Critically, the adoption of the nfP2X7 conformation exposes a unique epitope in the extracellular domain that is normally buried in the internal structure of the protein. Antibodies that recognise this epitope have been developed, and these have revealed significant overexpression of the nfP2X7 on many solid tumours including those originating from the breast, ovary, brain, prostate, skin, bowel, ovary, cervix, lung, pancreas, and stomach. In contrast, the expression of nfP2X7 is undetectable on healthy cells, including healthy cells within the proximal tissue of nfP2X7-positive tumour specimens (Barden JA, 2014, Gilbert et al., 2019, Worthington et al., 2002, Gilbert et al., 2017). NfP2X7 is thought to represent a conformationally constrained non-functional form of the receptor, which retains its ion transporter function without pore enlargement (Barden JA, 2014, Gilbert et al., 2019). As a result, cell death through this receptor is blocked, conferring a selective advantage on transformed cells. This may allow nfP2X7-positive cells to avoid apoptotic cell death in ATP-rich conditions such the tumour microenvironment, where ATP released by dying cells accumulate to extracellular concentrations in the hundreds of micromolar range (Barden JA, 2014). The expression of nfP $2 X 7$ on a diverse range of tumour cells is consistent with the notion that the receptor conveys a selective advantage on cancer cells, which is an attractive attribute for a CAR-T target 
(Gilbert et al., 2019, Barden JA, 2014). Indeed, siRNA-mediated knockdown of nfP2X7 on the nfP2X7positive prostate cancer cell line, PC3 resulted in apoptotic cell death (Gilbert et al., 2019).

To evaluate the potential of nfP2X7 as a broad range solid tumour target, we constructed a secondgeneration CAR-T cell therapy against nfP2X7 using an affinity matured peptide binding domain that binds to an exposed epitope on nfP2X7. Here, we demonstrate that nfP2X7-targeting CAR-T cellsgenerated from multiple donors display broad anti-tumour efficacy against twenty four cancer cell lines, representing twelve different cancer types. Finally, we demonstrate that nfP2X7-targeting CAR-T cells exhibit robust in vivo anti-tumour efficacy and long-term survival in triple-negative human breast cancer and prostate cancer xenograft mouse models. The almost ubiquitious expression of nfP2X7 on a diverse range of cancers is a major advantage of targeting nfP2X7 to generate a potentially universal CAR-T cell therapy. These results position nfP2X7-targeting CAR-T cells as a potential broad-spectrum immunotherapy against solid tumours in humans.

\section{Methods}

\section{Cancer cell lines and primary cells}

Details of all cell lines used in this study are listed in Supplementary Table 1. For in vitro cytotoxicity assays, cancer cell lines were transduced with a lentiviral vector encoding the genes for luciferase and green fluorescence protein (GFP) separated by the self-cleavage peptide T2A. Human $\mathrm{CD}^{+}{ }^{+} \mathrm{T}$ cells were isolated from whole blood or buffy coats obtained from anonymous healthy donors under consent (SSA/19/WCHN/96)(HEC/19/WCHN/65). Animal experiments were approved by the Animal Ethics Committee of the University of Adelaide and the University of South Australia (AEC\# U35-18, $\mathrm{S} / 2018 / 007)$. All experiments conformed to the guidelines established by the 'Australian Code of Practice for the Care and Use of Animals for Scientific Purposes'.

\section{CAR-T construct design}

The nfP2X7 binding domain was cloned into a well characterised second generation CAR vector backbone (Terakura et al., 2012, Wang et al., 2011), which encoded the hinge/linker region, CD28-derived transmembrane domain, intracellular signalling domains 41BB and CD3 zeta, self-cleavage peptide T2A and a truncated form of the EGFR receptor (EGFRt)(Paszkiewicz et al., 2016, Wang et al., 2011). We tested three hinge lengths short (nfP2X7-S: IgG4 hinge), medium (nfP2X7-M: IgG4 hinge-CH3) and long (nfP2X7$\mathrm{L}$ : IgG4 hinge- $\mathrm{CH} 2-\mathrm{CH} 3)$.

\section{Manufacture of lentivirus}

Lentivirus was produced by transfecting HEK 293T/17 cells (ATCC No-CRL11268) with the thirdgeneration self-inactivating lentiviral plasmid and the packaging plasmids encoding pCMV-Rev, pCMVVSV-G and psPAX2 (gag-pol), using the manufacturer's protocol for Lipofectamine 3000 (Thermofisher Scientific). Supernatants were collected $24 \mathrm{~h}$ and $48 \mathrm{~h}$ post-transfection and concentrated by 
ultracentrifugation at 50,000 RCF for $2 \mathrm{~h}$ at $4{ }^{\circ} \mathrm{C}$. The pellet was resuspended in Opti-MEM reduced serum media (Life Technologies) and stored at $-80^{\circ} \mathrm{C}$. Virus titres were determined by transduction of $1 \times 10^{5}$ HEK293T-17 or Jurkat cells with serial dilutions from 1:100 to 1:2000 of the concentrated virus in the presence of $8 \mathrm{ug} / \mathrm{ml}$ polybrene (Sigma-Aldrich), followed by analysis of EGFR reporter expression via flow cytometry. Titres were calculated based on reporter expression at 48h (Barry et al., 2000, Barry et al., 2001)

\section{T cell transduction and expansion}

$\mathrm{CD}^{+} \mathrm{T}$ cells were isolated from peripheral blood using the RosetteSep Human HLA T cell enrichment cocktail (StemCell) following the manufacturer's protocol. Cells were cultured in either complete X-VIVO ${ }^{\text {TM }}$ 15 Haematopoietic cell media (Lonza) supplemented with 2mM HEPES (Gibco) and 5\% human serum (Sigma-Aldrich) or complete X-VIVO ${ }^{\mathrm{TM}} 15$ Haematopoietic cell media supplemented with $2 \%$ KnockOut serum replacement (Gibco). Culture media was supplemented with the following cytokines (rhIL-2 50 $\mathrm{IU} / \mathrm{ml}$, rhlL-7 $5 \mathrm{ng} / \mathrm{ml}$, rhlL-15 0.5ng/ml) (Lonza or Miltenyi Biotec). CD3 ${ }^{+}$T cells were stimulated with aCD3/a-CD28 Dynabeads (Invitrogen), then transduced with lentivirus in the presence of $8 \mathrm{ug} / \mathrm{ml}$ polybrene. Beads were removed and transduction efficiency was determined on day 7 post-transduction. Transduced cells were stained with anti-EGFR monoclonal antibody (me1B3) (eBiosciences) and surface expression was analysed by flow cytometry. On day 8 post-isolation, cultures were further expanded by restimulation with peripheral blood mononuclear cells (PBMC). PBMCs were isolated using Ficoll Paque Plus (Sigma-Aldrich) or Ficoll-Paque Premium (GE Healthcare) density gradient centrifugation from buffy coats $(50 \mathrm{ml})$ obtained from LifeBlood (Adelaide) and frozen. Isolated PBMC were thawed and inactivated by irradiation on the day of T cell rapid expansion. Inactivated PBMC were added to the $T$ cell cultures, at a T cell to PBMC ratio of up to 1:50 in the presence of a soluble a-CD3 antibody ( $30 \mathrm{ng} / \mathrm{ml}$, OKT3) (Invitrogen). Cells were cultured for 12-14 days in G-Rex6® well plates (Wilson Wolf), with appropriate media changes and cytokine additions every 2-3 days. Cell counts and cell phenotype analysis were performed 14 days post-irradiated PBMC co-culture. Cells were routinely frozen on d15 post-PBMC for subsequent in vivo delivery.

\section{Design of a nfP2X7 peptide mimetic for flow cytometry}

To detect CAR surface expression and epitope specific binding, a biotin-labelled peptide was designed and synthesised (Genscript). This peptide consisted of a biotin moiety at the $\mathrm{N}$ terminus attached to the 16 amino acid sequence of P2X7 recognised by the CAR with a four amino acid (SGSG) linker.

\section{Immuno-phenotyping of CAR-T cells using flow cytometry}

Four different antibody panels were used to assess CAR-T cell phenotype. These included surface markers used to define the stage of cell maturation (CD45RA, CD45RO, CD62L and CCR7), cytotoxicity markers (IFNy, TNFa, IL-2, Granzyme B, Perforin and CD107a), activation markers (CD27, CD28, CD95, CXCR3) and co-inhibitory receptors/molecules (PD-1, CTLA-4, LAG-3, TIM-3, CD39). Antibodies are listed in Supplementary Table 2. 
Cultured T cells $\left(1 \times 10^{5}\right)$ or ex vivo single cell tumour suspensions $\left(1 \times 10^{6}\right)$ were stained in 96 -well roundbottom plates (Corning), using antibodies and related reagents detailed in Supplementary Table 2. For intracellular cytokine and cytotoxic molecule staining, cells were first incubated at $37^{\circ} \mathrm{C}, 5 \% \mathrm{CO}_{2}$ for 4 hours in complete IMDM (Gibco) supplemented with 10\% FCS (Sigma-Aldrich), 100U/ml penicillin/streptomycin (Gibco), 1x GlutaMAX (Gibco), 54pM $\beta$-mercaptoethanol (Sigma-Aldrich), 50ng/ml phorbol 12-myristate 13-acetate (Life Technologies), 1nM ionomycin (Life Technologies), 1/1500 GolgiStop (BD Biosciences) and 1/1000 GolgiPlug (BD Sciences or Biolegend). To stain CD107a, a directly conjugated antibody was added at the beginning of the PMA stimulation. All subsequent incubations were performed at room temperature unless stated otherwise. Cells were washed in PBS, before being stained with Fixable Viability Stain 780 (BD Biosciences) diluted 1/1000 and blocked with Human FC Block (BD Biosciences) for 10 mins. Cells were then washed in FACS buffer (PBS 1\% BSA, $0.04 \%$ azide) and stained for 30 mins with directly congjuated antibodies in Brilliant Stain Buffer (BD Biosciences). For intracellular staining, cells were incubated with Cytofix/Cytoperm (BD Biosciences) for 20 mins at $4^{\circ} \mathrm{C}$, washed in Perm/Wash buffer (BD Biosciences) and stained with intracellular directly conjugated antibodies for 30 mins at $4^{\circ} \mathrm{C}$. For the biotinylated nfP2X7 peptide mimetic, cells were stained with the peptide mimetic along with directly conjugated antibodies at room temperature, washed in FACS buffer and stained with streptavidin conjugated to BV421 (BD Biosciences) for 20 mins at $4^{\circ} \mathrm{C}$. After staining, cells were washed once with FACS buffer, washed once with PBS or PBS $0.04 \%$ sodium azide, resuspended in PBS $1 \%$ paraformaldehyde and stored at $4^{\circ} \mathrm{C}$ in the dark. Stained cells were acquired on the BD LSRFortessa X-20 flow cytometer within 5 days. Data analysis was performed using FlowJo Software V.10 (TreeStar, BD Biosciences). Gating strategies are detailed in Supplementary Figures 1-4.

\section{Cytokine release assay}

Activation of CAR-T cells was measured by cytokine release assays. Target cell lines were co-cultured with $\mathrm{CD} 4^{+} \mathrm{T}$ cells (control untransduced or CAR-T cells) for $24 \mathrm{~h}$ at $37^{\circ} \mathrm{C}$ and the concentration of cytokines; IL-2, IFN- $\$ and TNF-a in the supernatant was assayed using a Bio-Plex (Bio-Rad) validation kit.

\section{In vitro cytotoxicity analysis}

Two methods were used to assess cytotoxic activity of CAR-T cells in this study. Cytotoxicity was measured using a standard $4 \mathrm{~h}{ }^{51} \mathrm{Cr}$ release assay (Baumgaertner et al., 2016) using the following effector: target cell (E:T) ratios; 30:1, 10:1, 3.3:1, 1.1:1. Briefly, target cells were labelled with ${ }^{51} \mathrm{Cr}$ (5 $\mathrm{mCi} / \mathrm{ml}$ ) overnight at $37^{\circ} \mathrm{C}$ with $5 \% \mathrm{CO}_{2}$, and on the next day cells were washed with PBS and plated $\left(5 \times 10^{3}\right.$ cells/well in $\left.100 \mu l\right)$ in $96-w e l l$ plates. Effector cells were then added to the target cells at different ratios in triplicate in a total volume of $100 \mu \mathrm{l}$ and were co-cultured for $4 \mathrm{~h}$ at $37^{\circ} \mathrm{C}$ with $5 \% \mathrm{CO}_{2}$. Additional control wells with target cells alone were plated for each target cell line. To determine the maximum cytotoxicity, $100 \mu \mathrm{l}$ of $2 \%$ SDS solution was added to target cells alone. To determine the minimum cytotoxicity or assay background level, $100 \mu \mathrm{l}$ of media (RPMI media supplemented with $10 \%$ FCS) was plated. After $4 \mathrm{~h}$ incubation, $50 \mu \mathrm{l}$ of the supernatant was harvested and transferred to white LUMA plates. 
The LUMA plates were air-dried overnight and read using a TopCount scintillation counter (Perkin Elmer). Percentage cytotoxicity was calculated as (CPMsample-CPMMin)/ (CPMMax-CPMMin) x 100.

To replace the ${ }^{51} \mathrm{Cr}$ radioactive $\mathrm{CTL}$ assay with a safe non-radioactive equivalent, the Bright-Glo luciferase assay system (Promega) was used to determine the cytotoxicity of cancer cell lines by CAR-T cells.

Cancer cell lines stably expressing luciferase were used as target cells and seeded ( $1 \times 10^{4}$ in $50 \mathrm{ul}$ ) into a round bottom 96-well plate in triplicate for each condition tested. CAR-T cells (50 ul) were added to the target cells in the following effector: target ratios (10:1, 3:1, 1:1). Additional control wells of media alone and target cells alone were included to determine minimum luminescence and maximum luminescense, respectively. Cells were incubated for $16 \mathrm{~h}$ at $37^{\circ} \mathrm{C}$ with $5 \% \mathrm{CO}_{2}$ prior to the addition of Bright-Glo assay substrate (100 ul) (Promega) and further incubation for 4 mins at room temperature. An aliquot (100 $\mu$ l) of the mix was then transferred to an 96-well opaque plate (Nunc) and luminescence measured using a luminometer (GloMax Promega). Percentage cytotoxicity was calculated using the following fomula: 100 - [(Luminescence sample - luminescence media alone)/ (Luminescence target alone - luminescence media alone) $\times 100 \%]$.

\section{xCELLigence real time impedance/cytotoxicity assay}

E-plates (ACEA, Biosciences, San Diego, California, USA) were equilibrated in the XCELLigence ${ }^{\circledR}$ RTCA DP instrument (ACEA Biosciences) for 30 min with target cell media prior to the addition of target cells (2.4$3.0 \times 10^{4}$ cells in $100 \mu$ l of media). Impedance readings were taken every $15 \mathrm{~min}$ up to $16 \mathrm{~h}$ to establish a baseline and stabilised impedance. For measuring CAR-T cell cytotoxicity, target cell media (50 ul) was removed and effector cells were added at an E:T of 3:1 in 50 $\mu$ l of target cell media. Assays were performed in duplicates with impedance readings taken every $15 \mathrm{~min}$ for $72 \mathrm{~h}$. For analysis, the cell indices were normalised to the timepoint when the effector T cells were added. The area of the curves of the plots $72 \mathrm{~h}$ post- $T$ cell addition were measured and normalised to the untreated target cells as an indication of T cell killing efficacy.

In vitro cytotoxicity imaging

Target MDA-MB-231-LM2-GFP cells (a derivative of MDA-MB-231 cells, which were transduced to coexpress GFP) (Minn et al., 2005) were seeded at $5 \times 10^{4}$ cells in $300 \mu l$ target cell media per well of an ibiTreat 8 well $\mu$-slide (ibidi, Martinsried) and allowed to settle and spread overnight. CD3 ${ }^{+} \mathrm{T}$ cells were prepared at an E:T of $1: 1$ and pulsed with $5 \mu \mathrm{M}$ Fluo-4 AM (Invitrogen) at $37^{\circ} \mathrm{C}$ for 20 mins. The pulsed T cells were washed, resuspended in $200 \mu \mathrm{l}$ target cell media and added to the respective wells with $200 \mu \mathrm{M}$ propidium iodide (Invitrogen). Time-lapse images were captured at $10 \mathrm{sec}$ intervals for $3 \mathrm{~h}$ using a 40x objective lens on the LSM 700 laser scanning confocal microscope (Zeiss) using the Zen 2011 (black edition) software (Zeiss).

\section{Intravital microscopy histology analysis}


Female NOD-scid IL2Ry null (NSG) mice aged 6-8 weeks were purchased from Animal Resources Centre (Perth, Australia). NSG mice received a subcutaneous injection of $2 \times 10^{6}$ MDA-MB-231-LM2 cells, resuspended in a mix of $25 \mu \mathrm{l}$ cold PBS and $25 \mu \mathrm{l}$ Matrigel in the mammary fat pad. For intravital microscopy purposes, tumours were allowed to grow for 2 weeks prior to T cell injection. Prior to imaging, tumour-bearing mice were anaesthetised initially with isoflurane $/ \mathrm{O}_{2}$ before intraperitoneal injection of ketamine/xylazine $(10 \mathrm{mg} / \mathrm{ml}$, Ceva Animal Health). The midline of the mouse was then surgically opened, and the skin separated from the abdominal cavity to expose the tumour. nfP2X7-targeting $\mathrm{CD}^{+}$ CAR-T cells or untransduced $\mathrm{CD}^{+}$control cells $\left(2 \times 10^{7}\right.$ cells in $100 \mu$ l of PBS) pre-labelled with CellTracker Orange CMTMR (Invitrogen), together with $50 \mu \mathrm{l}$ of 50kDa Cy5 Dextran (Sigma), were injected intravenously though the tail vein. The mouse was then positioned under the LSM710 Two Photon Confocal Laser Scanning Microscope (Zeiss) with the tumour exposed under the objective lens. The tumour was excited with the Mai Tai Ti:Sapphire multiphoton laser (Spectra-Physics, Santa Clara, USA) and external non-descanned detectors used at $780 \mathrm{~nm}$ to capture the fluorescence signals to visualise the MDA-MB-231-LM2 cells expressing low levels of GFP, Cy 5 Dextran and CellTracker Orange labelled T cells. Time-lapse images were captured at $5 \mathrm{msec}$ intervals under the 20x/1.0 DIC W Plan-Apochomat objective (Zeiss, Carl Zeiss, Jena, Germany) using the Zen 2011 (black edition) software (Zeiss). Animals were euthanised at the experimental endpoint.

\section{Tumour tissue histology}

Tumours harvested from mice were processed as FFPE with $4 \mu \mathrm{m}$ sections, dewaxed and antigen retrieval performed using Tris-EDTA pH9.0 prior to tissues being blocked with $5 \%$ normal goat serum (NGS) in CAS-Block (Life Technologies) for $30 \mathrm{~min}$ at room temperature. Primary antibody (anti-CD3 antibody) (1:700; Cell Marque (Sigma-Aldrich)) diluted in CAS-Block plus 5\% NGS was added to the tissues and incubated overnight at $4^{\circ} \mathrm{C}$. After washing, secondary antibody Alexa-555 (goat anti-rabbit, 1:500, ThermoFisher Scientific) was prepared in CAS-block with $5 \%$ NGS and incubated for $2 \mathrm{~h}$ at room temperature. Slides were counterstained with DAPI (1:2000,ThermoFisher Scientific) and imaged using the Zeiss 800 microscope.

\section{Xenograft Mouse Models}

Tumour cell lines were cultured according to the conditions detailed in Supplementary Table 1. On the day of injection, adherent cells were rinsed in PBS, incubated with trypsin-EDTA solution (Gibco) at $37^{\circ} \mathrm{C}$, washed once in culture medium and twice in PBS. Cells were kept on ice until injection. NSG mice were anaesthetised using isofluorane (Henry Schein). For the MDA-MB-231 human breast cancer model, 7-9 week old female NSG mice were injected subcutaneously into the 4th left mammary fat pad (L4) with $2 \times 10^{6}$ MDA-MB-231 cells resuspended in sterile PBS:Matrigel such that the final protein concentration was $4-6 \mathrm{mg} / \mathrm{ml}$. Cells were injected in a $45-50 \mu \mathrm{l}$ volume using a $26 \frac{1}{2}$ gauge needle attached to a $50 \mu \mathrm{l}$ glass syringe (Hamilton Company, NV, USA). For the PC3 model, 7-9 week old male NSG mice were injected subcutaneously into the lower abdomen with $1 \times 10^{6} \mathrm{PC} 3$ cells resuspended in sterile PBS. Cells were injected in a $200 \mu \mathrm{l}$ volume using a $26 \frac{1}{2}$ gauge needle attached to a $1 \mathrm{ml}$ Luer lock syringe (BD 
Biosciences). Tumours were measured every 2 days beginning on $\mathrm{d} 7$ post-tumour injection using digital callipers (Mitutoyo, Japan) by measuring the longest distance as length and the perpendicular distance as width. Tumour size was calculated as the multiple of length and width measurements. The health status of mice was monitored daily and mice were euthanized when the tumours became ulcerated, tumour length was equal to or greater than $15 \mathrm{~mm}$, tumour size was equal or greater than $100 \mathrm{~mm}^{3}$ or when mice displayed a combination of disease symptoms including any of the following: ruffled coat, hunched posture, reluctance to move, laboured breathing, weight loss of $10 \%$ or more of initial weight and/or changes in behaviour or gait. For intravenous transfer of T cells, CAR-T cells or untransduced T cells were thawed and resuspended in sterile dPBS. Mice were restrained and injected with a cell suspension via the tail vein at day 3 or 7 post-tumour injection. Tumour measurements, monitoring and T cell injections were performed with groups blinded.

\section{Preparation of Tumour Homogenates}

Tumours were excised, manually minced into small pieces and incubated in warm digest media for 1-1.5 hours at $37^{\circ} \mathrm{C}$ with continuous gentle agitation. Tumours were mixed every $15-20$ min by resuspension. Digest media was prepared by supplementing DMEM (Gibco) with $5 \%$ heat-inactivated FCS (SigmaAldrich), 2.5mM CaCl $2,10 \mathrm{mM}$ HEPES (Gibco), 100U/ml penicillin/streptomycin (Life Technologies), $30 \mathrm{U} / \mathrm{ml}$ DNase I (Sigma-Aldrich) and $1 \mathrm{mg} / \mathrm{ml}$ collagenase IA (Sigma-Aldrich). Tumour homogenates were

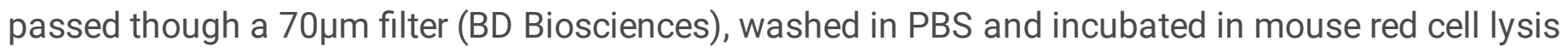
buffer for $5 \mathrm{~min}$ at $37^{\circ} \mathrm{C}$. Cells were then washed in PBS and stained for analysis by flow cytometry.

\section{Results}

\section{Linker length impacts the antigen-specific cytotoxicity of nfP2X7-CAR-T cells.}

To generate a nfP2X7-targeting CAR, a nfP2X7 peptide-binding domain was cloned into a secondgeneration CAR lentiviral backbone encoding a IgG4 hinge/linker and intracellular domains from 41BB and CD3 zeta, connected by a T2A self-cleaving peptide to a truncated EGFR (EGFRt) reporter (Turtle et al., 2016, Jensen and Riddell, 2015, Wang et al., 2011, Wang et al., 2012). As the target epitope must be captured within a functional immunological synapse, the tertiary structure of the extracellular domain of the CAR impacts the antigen binding and activity of the CAR-T cell. The hinge region is used to connect the antigen-binding domain to the transmembrane domain, and the hinge length can play an important role in optimal CAR activity. Therefore to optimize the tertiary structure of the nfP2X7-targeting CAR, we tested three different hinge lengths to find the most effective combination for maximum cytotoxicity (Figure 1A). The following coding was used to identify each CAR-T construct: nfP2X7-S (IgG4 hinge), nfP2X7-M (IgG4 hinge-CH3) and nfP2X7-L (IgG4 hinge-CH2-CH3). The long hinge used here comprised a modified $\mathrm{CH} 2$ domain to prevent binding to $\mathrm{FC} \rrbracket$ receptors which can cause off-target cytotoxicity (Hudecek et al., 2015). To determine the optimum linker length, donor-matched CD ${ }^{+}$and $C D 4^{+}$cells were isolated as separate populations and transduced with lentiviruses encoding the nfP2X7-specific CAR with one of three different hinge lengths. Following $T$ cell expansion, transduction efficiency was assessed by 
EGFR reporter expression. All constructs were transduced into T cells at a high efficiency, with a larger percentage of of nfP2X7-S (99.2\% of CD4 $4^{+}, 92.0 \%$ of CD8 $\left.{ }^{+}\right)$and nfP2X7-M $\left(98.2 \%\right.$ of $C D 4^{+}, 93.1 \%$ of $\left.\mathrm{CD}^{+}\right)$cells expressing EGFR. The nfP2X7-L construct displayed comparatively lower expression of EGFR $\left(85.7 \%\right.$ of $\mathrm{CD} 4+, 70.9 \%$ of $\left.\mathrm{CD}^{+}\right)$(Figure $\left.1 \mathrm{~B}\right)$.

As it has been well-established that $\mathrm{CD} 8^{+} \mathrm{T}$ cells mediate direct tumour cytolysis while $\mathrm{CD} 4^{+} \mathrm{T}$ helper cells provide cytokines to support $C D 8^{+} T$ cell cytotoxicity, the cytotoxic potential of $C D 8^{+} T$ cells was assessed in in vitro cytotoxicity assays and cytokine production of $\mathrm{CD} 4^{+} \mathrm{T}$ cells was assessed in cytokine release assays. The cytotoxicity potential of $\mathrm{CD} 8^{+} \mathrm{CAR}-\mathrm{T}$ cells, which varied according to hinge length, was compared using a ${ }^{51} \mathrm{Cr}$ release assay against five cancer cell lines: MDA-MB-231 (breast cancer), U87 (glioma), M21 (melanoma), SK-ND-Z (neuroblastoma) and K562 (leukemia). As a positive control, we used K562 cells that were transduced to express the anti-CD3 antibody, OKT3. Briefly, CAR-T cells were cocultured with target cancer cell lines at effector cell: target cell (E:T) ratios of 10:1, 3:1 and 1:1 for $4 \mathrm{~h}$. Untransduced donor-matched $\mathrm{CD} 8^{+} \mathrm{T}$ cells prepared in parallel alongside CAR-T cells from the same donor, were used as a negative control to measure non-specific cytotoxicity. All CD $8^{+}$cells demonstrated high levels of cytolytic activity against K562-OKT3 cells (positive control), indicating that all (CAR-T and untransduced) populations were able to mount an effective cytolytic responses as a result of polyclonal activation. Out of the three CAR-T cell populations tested, nfP2X7-M CAR-T cells showed significant dosedependent cytotoxic activity towards MDA-MB-231 (43\%), U87 (25\%), and M21 (21\%) cell lines at a E:T ratio of 30:1, but did not demonstrate activity against SK-ND-Z or K562 cells (Figure-1C). The other two CAR-T cell formulations (nfP2X7-S or nfP2X7-L) did not show in vitro antigen-specific cytotoxicity against any of the tumour cell lines tested despite showing comparable levels of transgene expression and cytotoxic response to the control target cells (K562-OKT3). Together, these data indicate that hinge length significantly impacts the antigen-specific cytotoxicity of nfP2X7-targeting CAR-T cells in vitro.

Furthermore, the production of $\mathrm{T}_{\mathrm{H}} 1$ cytokines by $\mathrm{CD} 4^{+} \mathrm{CAR}-\mathrm{T}$ cells, which harboured the three different hinge lengths was assessed. All CD $4^{+}$CAR-T cell populations demonstrated equivalent cytokine

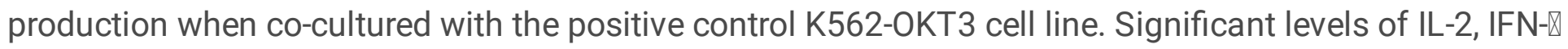
and TNF- $a$ were detected in supernatants of CD $4^{+}$nfP2X7-M-CAR-T cells co-cultured with MDA-MB-231 and U87 cancer cell lines but not when co-cultured with either SK-ND-Z or K562 cells (Figure-1D). This was consistent with the cytotoxic function of $\mathrm{CD}^{+}{ }^{+}$nfP2X7-M CAR-T cells observed in vitro. Furthermore, minimal concentrations of $T_{H} 1$ cytokines were detected in the culture media from $C D 4^{+} T$ cells expressing nfP2X7-S or nfP2X7-L in response to co-culture with cancer cells, which was also consistent with the results of the cytotoxicity assays with $\mathrm{CD} 8^{+} \mathrm{CAR}-\mathrm{T}$ cells. Based on the enhanced antigen-specific cytotoxicity and cytokine release profile of the nfP2X7-M CAR, we selected this CAR for all subsequent in vitro and in vivo experiments.

nfP2X7-CAR-T specific killing of a broad range of cancer cell lines in vitro. 
To further investigate the cytotoxicity potential of the nfP2X7-M CAR-T cells, we tested these cells against a more comprehensive range of cancer cell lines, including 24 different cancer cell lines from 12 cancer types. From this point onwards, bulk $\mathrm{CD}^{+} \mathrm{T}$ cells were used for CAR-T cell production. This strategy was selected as it yields transduced $\mathrm{CD} 4^{+}$and $\mathrm{CD} 8^{+}$in a single transduction protocol. Using this combined $\mathrm{CD}^{+} \mathrm{T}$ cell protocol, consistently high transduction efficiency $(>77 \%)$ by the CAR lentivirus was observed (Figure $2 \mathrm{~A})$. The $\mathrm{CD} 8^{+} / \mathrm{CD} 4^{+}$ratio on d 14 post-stimulation with PBMC skewed towards a higher frequency of $\mathrm{CD}^{+} \mathrm{T}$ cells, with a 2.95:1 mean $\mathrm{CD} 8^{+}: \mathrm{CD} 4^{+}$ratio in the untransduced populations and a 1.83:1 mean $\mathrm{CD} 8^{+}: \mathrm{CD} 4^{+}$ratio in the CAR-T cell populations (Figure $2 \mathrm{~A}$ ). As the normal $\mathrm{CD} 8^{+} / \mathrm{CD} 4^{+}$ratio in human peripheral blood is 1:2.3 (McBride and Striker, 2017), Supplementary Figure 5), these data indicate that the skewing toward $\mathrm{CD} 8^{+} \mathrm{T}$ cells is a consequence of the manufacturing process. A selection of surface markers was used to define cytotoxic potential, the stage of cell maturation, activation, and co-inhibitory molecule expression for all preparations of untransduced control and CAR-T cells (Supplementary Table 2). After expansion, $T$ cells comprised of a heterogeneous population consisting of mostly naïve-like $\left(T_{N}\right.$, $\mathrm{CD}_{45 A^{+}}$and $\left.\mathrm{CD} 62 \mathrm{~L}^{+}\right)$, central memory $\left(\mathrm{T}_{\mathrm{CM}}, \mathrm{CD} 45 \mathrm{RA}^{-}\right.$and $\left.\mathrm{CD} 62 \mathrm{~L}^{+}\right)$and stem cell memory $\left(\mathrm{T}_{\mathrm{SCM}}\right.$,

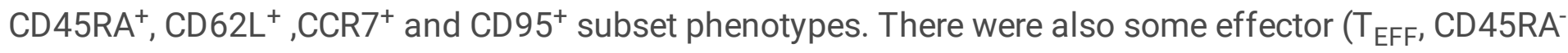

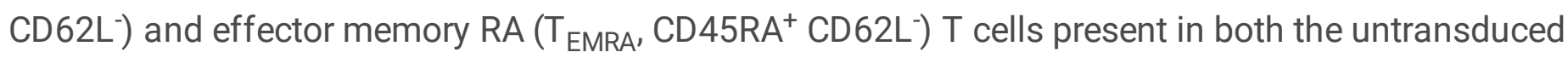
control and CAR-T cell populations (Figure 2B). The short duration of CAR-T cell culture expansion (14 days) retained a large percentage of naïve-like and central memory phenotypes (Figure 2B). There was comparable expression of activation markers $\left(\mathrm{CD} 27^{+}, \mathrm{CD} 28^{+}\right.$and $\left.\mathrm{CD} 95^{+}\right)$in both untransduced control and CAR-T cells populations at the end of expansion (Supplementary Figure 6A). Furthermore, extremely low expression of the co-inhibitory markers CTLA4, PD1, LAG3 and TIM3 (Supplementary Figure 6B) and high expression of cytotoxicity markers TNFa, IFN囚, IL-2, perforin, granzyme B and CD107a was observed (Supplementary Figure 7C). To demonstrate antigen-specific binding by the CAR construct, we stained untransduced and CAR-T cells with a biotin-labelled peptide mimetic of the nfP2X7 epitope. To correlate the frequency of CAR-T cells that were EGFR ${ }^{+}$and were capable of binding to the $\mathrm{nfP} 2 \mathrm{X} 7$, simulateneous surface staining with anti-EGFR and the nfP2X7 peptide mimetic was performed.. The frequency of stained cells using either reagent were not significantly different, demonstrating EGFR expression is a reliable reporter of CAR expression (Supplementary Figure 8A). These data also indicated that nfP2X7targeting $\mathrm{CD}^{+} \mathrm{CAR}-\mathrm{T}$ cells were capable of specifically recognising the cognate target antigen and displaying highly antigen-specific killing. Taken together, nfP2X7-targeting CAR-T cells were transduced at a high transduction efficiency and displayed a favourable $T$ cell phenotype characterized by minimal differentiation and co-inhibitory molecule expression and high frequencies of activation and cytotoxic molecule expression.

To determine the cytotoxicity potential of the nfP2X7-M CAR-T on multiple cancer types we next used a luminescence-based cytotoxicity assay. Briefly, effector CAR-T cells were co-cultured with cancer cells (target cells) stably expressing luciferase at E:T ratios of 10:1, 3:1 and 1:1 for $16 \mathrm{~h}$. Significantly higher CAR-T cell-specific cytotoxicity was observed compared with untransduced control cells against the majority of the cancer cell lines tested. The highest level of cytotoxicity was observed against the C32 
(melanoma), SK-MEL-28 (melanoma), Be(2)-M17 (neuroblastoma) and RD (rhabdomyosarcoma) cell lines. A titration dependent effect was also observed, with percentage cytotoxicity values decreasing as the E:T ratio decreased (Figure $2 \mathrm{C}$ ). Some cancer targets were more efficiently killed by the $\mathrm{CD}^{+}{ }^{+} \mathrm{nfP} 2 \mathrm{X7}$ M CAR-T cells than others, which is summarised as a heatmap of tumour cell lysis percentage at the E:T of 10:1 (Figure 2D). Taken together, these data show that nfP2X7-targeting CAR-T cells are cytotoxic against 22 out of 24 different cancer cell lines tested in vitro, demonstrating broad cancer specificity. Furthermore, real-time cytotoxicity assays were performed using the xCELLigence impedance system to assess the kinetics of CAR-T cell cytotoxicity in vitro. Co-culture of nfP2X7-M CAR T cells with three human cancer cell lines (MDA-MB-231, PC3, OVCAR3) resulted in significantly lower impedance of tumour cells, represented as a normalized cell index, compared with untransduced donor-matched control T cells. This demonstrated that CAR-T cells mediate significant and prolonged anti-tumour cytotoxicity against cancer cell lines, which resulted in almost complete elimination of cancer cells after 70h coculture (Figure 2E,F).

To investigate potential off-target activity of nfP2X7-targeting CAR-T cells, in vitro cytotoxicity assays were performed using normal healthy PBMCs. PBMCs were selected as wild type P2X7 was reported to be expressed on many haemapoietic cells including, monocytes, macrophages, B cells, $T$ cells, dendritic cells and natural killer cells (Gu et al., 2000, Lara et al., 2020). To test in vitro cytotoxicity using the luciferasebased method, PBMCs were first transduced with the lentivirus, LV-GFP-Luc to stably express firefly luciferase, and cytotoxicity mediated by nfP2X7-M-CAR-T cells or untransduced control $\mathrm{CD}^{+}{ }^{+} \mathrm{T}$ cells was assessed as previously described. In this assay, even at the highest dose of nfP2X7-M CAR-T cells, no cytotoxicity against PBMC cells was detectable (Supplementary Figure 9A), indicating that these CAR-T cells do not respond to the functional wild-type form of P2X7.

nfP2X7-targeting CAR-T cells engage with and elicit effector function against cancer cells in vitro and in vivo

To gain initial insight into the possible interactions between CAR-T cells and tumours in vivo, intravital microscopy was performed on anaesthetised mice harbouring orthotopic GFP-tagged MDA-MB-231-LM2 tumours. Tumours were allowed to establish for approximately 2 weeks prior to intravenous injection of $50 \mathrm{kDa}$ Cy 5 Dextran to visualise the tumour vasculature. At this point, $T$ cells were labelled with CellTracker Orange and administered into MDA-MB-231-tumour-bearing mice and tumours were imaged by multi-photon microscopy. As shown in the representative images in Figure 3A, transferred nfP2X7targeting CAR-T cells were identified as circulating cells within the tumour vasculature (white outline) within 2 min post-administration. Within the $<1 \mathrm{~mm}$ visual limitations into the tumour mass, nfP $2 X 7$ CART cells were observed to adhere to the vascular walls (Figure 3A left panel, Supplementary Video 1) and transmigrate though the endothelial cell wall (Figure 3A center and right panels, Supplementary Video 1). Intravital imaging revealed that a relatively small proportion of the circulating $T$ cells entered the tumour mass. However there were no quantifiable differences in tumour infiltration between untransduced and nfP2X7 CAR-T cells observed by real-time imaging following the 4 hours post-T cell administration (data not shown). To provide quantitation of CAR-T cell infiltration, in similar experiments, MDA-MB-231-LM2 
and PC3 tumours were harvested approximately 2 weeks post-T cell injection and processed for immunofluorescence analysis. As shown in Figure $3 \mathrm{~B}$, there were more $\mathrm{CD}^{+} \mathrm{DAPI}^{+} \mathrm{T}$ cells within the tumours of mice treated with nfP2X7-M CAR-T CAR T cells compared with mice that were administered untransduced T cells. These results indicate that while both nfP2X7-M CAR T cells and untransduced T cells are able to traffic to and infiltrate the tumour parenchyma, nfP2X7-M CAR T cells were preferentially retained within tumours, possess increased survival and proliferation and/or decreased apoptosis. Furthermore, in vitro real-time imaging revealed nfP2X7-M CAR-T cells were able to directly engage with and promote tumour cell death while untransduced cells exhibited almost no tumour cell engagement and cytotoxicity (Figure 3C, Supplementary Video 2).

\section{nfP2X7-targeting CAR-T cells inhibit human tumour xenograft growth in vivo.}

To investigate the in vivo anti-tumour efficacy of nfP2X7-M CAR-T cell therapy, CAR-T cells were delivered into two different human tumour xenograft models, MDA-MB-231 and PC3. MDA-MB-231 breast cancer and PC3 prostate cancer were selected for in vivo testing of nfP2X7-targeting CAR-T cells as these cell lines represent two of the most common types of cancer and have been widely studied as preclinical models of human tumour xenografts (Sung et al., 2021, Song et al., 2016, Han et al., 2018, Wei et al., 2018, Wei et al., 2020, Zuccolotto et al., 2014, Deng et al., 2015). Prior to injection, untransduced and CART cells displayed similar activation, cytotoxicity, co-inhibitory receptor and T cell subset phenotypes (Supplementary Figure 6 and 7). Intravenous administration of 2x107 nfP2X7-M CAR-T cells on day 3 post-inoculation of mice with MDA-MB-231 cells significantly inhibited tumour growth. This was reflected in both tumour size at $\mathrm{d} 39$ post-tumour injection and tumour weights at $\mathrm{d} 40$ post-tumour injection; with tumour sizes and weights of $59.78 \pm 3.27 \mathrm{~mm}^{2}, 267.79 \pm 24.89 \mathrm{mg}$ in mice receiving untransduced T cells and $32.4 \pm 2.27 \mathrm{~mm}^{2}, 133.5 \pm 18.69 \mathrm{mg}$ in mice receiving CAR-T cells (mean size \pm SEM, Figure 4A). Ex vivo analysis of tumours at endpoint recovered significantly higher frequencies of human $\mathrm{CD} 3^{+} \mathrm{T}$ cells in mice administered nfP2X7-M CAR-T cells compared to untransduced control cells (Figure 4B).

Furthermore, there was an increase in the $\mathrm{CD} 4^{+}: \mathrm{CD} 8^{+} \mathrm{T}$ cell ratio in the intratumoral CAR-T cell population with a ratio of 3.4:1 compared to 1.1:1 for recovered untransduced cells (Figure 4B). T cell subsets were assessed by $\mathrm{CD} 45 \mathrm{RO}$ and $\mathrm{CD} 62 \mathrm{~L}$ expression, which identified the majority of intratumoural cells in mice receiving nfP2X7-M CAR-T cells as $\mathrm{CD} 45 \mathrm{RO}^{+} \mathrm{CD}^{+} 2 \mathrm{~L}^{-} \mathrm{T}_{\mathrm{EM}}\left(89.9 \pm 1.97 \%\right.$ of $\mathrm{CD} 4^{+}, 64.5 \pm 5.12 \%$ of $\left.\mathrm{CD} 8^{+}\right)$ with low frequencies of $\mathrm{CD} 45 \mathrm{RO}^{+} \mathrm{CD} 6 \mathrm{~L}^{+} \mathrm{T}_{\mathrm{CM}}$ and $\mathrm{CD} 45 \mathrm{RO}^{-} \mathrm{CD}^{-} \mathrm{L}^{-} \mathrm{T}_{\mathrm{EFF}}$ cells also present (Figure $4 \mathrm{C}$ ). This was accompanied by a marked increase in the frequencies of co-inhibitory receptor expression on ex vivo recovered T cells. In the $\mathrm{CD} 4^{+}$compartment of T cells recovered from CAR-T cell treated mice, $90.8 \pm$ $1.39 \%$ and $55.7 \pm 2.55 \%$ were found to be PD $-1^{+}$and CTLA $-4^{+}$, respectively. In the $\mathrm{CD} 8^{+}$compartment, $14.4 \pm 1.54 \%$ expressed CTLA-4 and variable expression of PD- 1 ranging from 9 to $85 \%$ was detected. Furthermore, LAG-3 was expressed by $17.65 \pm 2.68 \%$ and $51.5 \pm 4.38 \%$ of $C D 4^{+}$and $C D 8^{+} T$ cells, respectively (Figure 4D). The dramatic phenotypic changes observed in the intratumoural CAR-T cell population compared with their pre-injection phenotype (Supplementary Figure 6 and 7) indicate CAR-T 
cells likely form antigen-specific interactions with tumour cells and are chronically activated in the tumour microenvironment.

To further explore the potential tumour targeting of nfP2X7-M CAR-T cells, we tested a second human solid tumour model. In this model, NSG mice were injected subcutaneously with PC3 prostate cancer cells and 3 to 7 days later, were administered with a single dose of $2 \times 10^{7}$ nfP2X7-M CAR-T cells via the intravenous route. This resulted in a highly significant inhibition of tumour growth (mean size \pm SEM 4.4 $\pm 0.90 \mathrm{~mm}^{2}$ at $\mathrm{d} 27$ post-tumour injection) compared to mice receiving untransduced cells $(62.6 \pm 5.46$ $\mathrm{mm}^{2}$ ) (Figure 5A). This was also reflected in the final tumour weight (CAR-T: $68.51 \pm 17.66$, untransduced: $384.0 \pm 22.0 \mathrm{mg}$ ) (Figure 5A, right panel). Similar to MDA-MB-231 tumours, nfP2X7-M CAR-T cells were significantly enriched in tumours compared with untransduced $C D 3^{+} \mathrm{T}$ cells, with human $\mathrm{CD}^{+} \mathrm{T}$ cells comprising $10.27 \pm 1.69 \%$ of total live cells in tumours of nfP2X7-M CAR-T-injected mice.This is in contrast to the extremely low to undetectable infiltration of untransduced cells in control mice (Figure 5B, left and center panels). In this model, the $\mathrm{CD} 4^{+}: \mathrm{CD} 8^{+}$ratio of recovered CAR-T cells was 5:1 (Figure $5 B$, right panel). This increased proportion of $C D 4^{+} \mathrm{T}$ cells recovered from tumours compared to the input $C D 4^{+}: \mathrm{CD} 8^{+}$ratio (Figure $2 \mathrm{~A}$ ) was consistent with the results observed in the MDA-MB-231 breast cancer model.

In the PC3 model, co-inhibitory receptor expression increased significantly ex vivo in both the CD $4^{+}$ compartment $\left(59.9 \pm 6.58 \% \mathrm{PD}-1^{+}\right.$and $\left.77.17 \pm 5.69 \% \mathrm{CTLA}^{+} 4^{+}\right)$and the CD $8^{+}$compartment $(31.4 \pm 8.4 \%$ PD $-1^{+}$and $74.0 \pm 5.87 \%$ CTLA- $4^{+}$) (Figure 5D). In comparison, approximately $10 \%$ and $5 \%$ of input cells expressed CTLA-4 and PD-1, respectively (Supplementary Figure 6B). Furthermore, LAG-3 was expressed on $44.5 \pm 3.79 \%$ of the $\mathrm{CD} 4^{+}$compartment and $6.14 \pm 0.88 \%$ of the $\mathrm{CD} 8^{+}$compartment of ex vivo recovered $T$ cells. Together, these data suggest a high level of activation in the tumour microenvironment (Figure 5D). Notably, in one experiment, $2 \times 10^{7} \mathrm{nfP} 2 \mathrm{X} 7$-targeting CAR-T cells led to rapid tumour rejection and complete loss of palpable tumours 18 days post-T cell transfer. These mice exhibited significantly prolonged survival (90 days post-tumour injection) compared with mice receiving PBS and untransduced $\mathrm{CD}^{+} \mathrm{T}$ cells (Supplementary Figure 10).

\section{Discussion}

CAR-T cell immunotherapy holds great promise in the treatment of cancer. However, to date, success has been limited to haematological malignancies. While there are a number of CAR-T cell therapies currently undergoing early clinical trial for treatment of solid tumours, many challenges remain including selection of tumour-specific antigen targets and identification of the optimal phenotype of CAR-T cells required for effective eradication of solid tumours. Moreover, the generation of novel CARs with anti-tumour efficacy against a broad range of solid tumours represents an attractive strategy. In the present study, we investigated the non-functional form of the purinergic receptor $\mathrm{P} 2 \mathrm{X} 7, \mathrm{nfP} 2 \mathrm{X7}$, as a candidate target antigen for CAR-T cell therapy, based on observations that the non-functional form is exclusively expressed on cancers and is antigenically distinct from the functional form found on healthy tissues 
(Barden JA, 2014, Barden et al., 2016, Gilbert et al., 2019). Several therapeutic advantages are presented by generating an nfP2X7-specific CAR. The nfP2X7 antigen is expressed on multiple cancer types, and is a unique cancer-specific epitope, rather than an endogenous antigen overexpressed on cancer cells. This raises the possibility of generating a pan-cancer CAR-T cell therapy with minimal on-target off-cancer effects.

We used the binding region from a peptide binder engineered from a heavy chain variable domain that had undergone multiple rounds of random mutagenesis and phage display affinity purification to design the nfP2X7-specific CAR binding domain, and established gene delivery and cell culture protocols for generation of sufficient number of CAR-T cells with a favourable T cell phenotype for validation of efficacy. To optimise CAR-T cell target recognition, we investigated the effect of different hinge region lengths of the CAR. As previously described, the optimal hinge length is known to vary depending on the target antigen and the relative position of the epitope on the cell surface (Hudecek et al., 2015). This dependence on hinge length is likely due to the need to form an optimal immunological synapse for $T$ cell activation (Guest et al., 2005, Hudecek et al., 2015). In addition, the hinge region can influence CAR-T cell phenotype and migration capacity independently of tumour antigen binding (Watanabe et al., 2016). Our data confirm that hinge length plays an important role in determining the activity of nfP2X7-targeting CAR T cells, as only T cells expressing a CAR with the medium (IgG4 hinge-CH3) linker demonstrated cytokine release and cytotoxicity against the cancer cell lines tested in vitro. This result does not appear to be due to a difference in surface CAR expression levels, as the frequency of EGFRt reporter expression of the medium hinge length ( $\mathrm{nfP} 2 \mathrm{X} 7 \mathrm{M}$ ) CAR was not significantly different to short (nfP2X7-S) and long (nfP2X7-L) hinge length CAR-T cells. Given that all three CARs express the same binding domain, but only the medium length hinge induces potent cytotoxicity, we infer this specific hinge forms the required spatial interaction with the epitope, resulting in T cell activation via the intracellular domains. These results clearly demonstrate the importance of testing CARs with a library of hinge lengths to identify the optimal CAR formulation for activity.

As initial CAR-T cell growth in recombinant human IL-2 resulted in sub-optimal expansion and favoured a terminally differentiated CAR-T cell phenotype (data not shown), further optimisation of the manufacture process involved including IL-7 and IL-15 in combination with IL-2. This cytokine cocktail was utilized during CAR-T cell rapid expansion as extensive studies have shown that IL-7 and IL-15 preferentially expand memory sub-populations such as $\mathrm{T}_{\mathrm{CM}}$ and $\mathrm{T}_{\mathrm{SCM}}$ subset phenotypes (Schmueck-Henneresse et al., 2017, Xu et al., 2014, Cieri et al., 2013, Alizadeh et al., 2019, Hurton et al., 2016).

Whilst our screening to identify the lead CAR-T cell formulation was performed using purified $\mathrm{CD} 8^{+} \mathrm{T}$ cells, we pivoted to generate $\mathrm{CAR}-\mathrm{T}$ cells from a $\mathrm{CD}^{+} \mathrm{T}$ cell pool. This gave the advantage of generating a mixed $\mathrm{CD} 4^{+}$and $\mathrm{CD} 8^{+}$CAR-T cell population from a single transduction event, potentially simplifying manufacturing and reducing the cost of production of the therapy. Furthermore, $\mathrm{CD} 4^{+} \mathrm{T}$ cells display key advantages for adoptive $T$ cell therapy. For instance, $C D 4^{+} T$ cells have been demonstrated to directly lyse tumour cells, possess enhanced in vivo persistence relative to $\mathrm{CD} 8^{+} \mathrm{T}$ cells and in some models, elicit 
superior anti-tumour activity compared with CD8 ${ }^{+}$T cells (Wang et al., 2018, Zhang et al., 2020, Yang et al., 2017, Agarwal et al., 2020). Indeed, the increased $C D 4^{+}: C D 8^{+}$ratio observed in T cells recovered from MDA-MB-231 and PC3 tumours may reflect enhanced persistence of $\mathrm{CD} 4^{+}$T cells in vivo. In addition, many reports have shown that mixed $\mathrm{CD} 4^{+} / \mathrm{CD} 8^{+} \mathrm{CAR}-\mathrm{T}$ populations are more effective in controlling in vivo tumour growth than CD8 ${ }^{+}$CAR-T cells administered alone (Moeller et al., 2005, Sommermeyer et al., 2016).

A key requirement for clinical translation of CAR-T cell therapy is robust expansion of CAR-T cells that retain desirable phenotypic attributes, such as naïve and memory subset phenotypes that possess enhanced self-renewal capacity and are favourable for long-term protective immune surveillance to prevent relapse (Gargett and Brown, 2015, Irving et al., 2017). By testing a range of different culture conditions and using a combination of $T$ cell growth factors, we were successful in generating a CAR-T cell pool comprising a mix of $\mathrm{T}_{\mathrm{N}}, \mathrm{T}_{\mathrm{CM}}, \mathrm{T}_{\mathrm{EFF}}$, and $\mathrm{T}_{\mathrm{EMRA}}$ subset phenotypes. Importantly, approximately $40 \%$ of the CD45RA ${ }^{+}$CD $62 \mathrm{~L}^{+}$naïve population displayed a $\mathrm{T}_{\mathrm{SCM}}$ phenotype, which were defined as $\mathrm{CD} 4 \mathrm{RA}^{+}, \mathrm{CD} 6 \mathrm{~L}^{+}, \mathrm{CCR} 7^{+}$and $\mathrm{CD}^{+} 5^{+}$in line with previously published studies(Gattinoni et al., 2011, Gargett et al., 2019). These cells possess the ability to self-renew, are highly proliferative, differentiate into memory and effector phenotypes and possess superior persistence and antitumour effects in many cancer immunotherapy models when compared with other T cell subsets (Irving et al., 2017, Golubovskaya and Wu, 2016, Gattinoni et al., 2011, Xu et al., 2014, Busch et al., 2016, Blaeschke et al., 2018, Sabatino et al., 2016). We generated a low percentage of effector memory cells consistent with clinically efficient CAR-T cell populations (Biasco et al., 2021). Although effector $T$ cells possess potent cytotoxicity ability in vitro, they have limited proliferation capacity and persistence in vivo and express higher levels of exhaustion-associated markers (Terakura et al., 2012, Schmueck-Henneresse et al., 2017). Hence the combination of $T_{N}, T_{S C M}$ and $T_{C M} T$ cell subsets may provide the most durable anti-tumour protection. Furthermore, the low expression of multiple co-inhibitory molecules associated with $T$ cell dysfunction such as PD-1, CTLA-4 and LAG-3, as observed in the optimised nfP2X7-M CAR-T cells generated in the present study, has been correlated with increased anti-tumour efficacy (Zou et al., 2019). Using our current expansion protocol, we observed TIM-3 expression on a large percentage $(>70 \%)$ of untransduced and CAR-T cells in both the $\mathrm{CD} 4^{+}$and $\mathrm{CD} 8^{+}$compartments. The role of TIM-3 as a coinhibitory or co-stimulatory receptor is somewhat controversial. High frequencies of $\mathrm{TIM}^{-} 3^{+}$in CAR-T cell populations has also been reported by several other groups (Zhao et al., 2015, Lynn et al., 2019, Zhang et al., 2017, Schneider et al., 2021). However, the expression of TIM-3 does not seem to impair CAR-T cell in vivo anti-tumour efficacy as demonstrated by the work described here and by others (Schneider et al., 2021, Zhao et al., 2015). Furthermore, expression of TIM-3 without PD-1, LAG-3 or CTLA-4 on the majority of CAR-T cells suggest these cells are not highly dysfunctional (Singer et al., 2016, Liu et al., 2016, Sawada et al., 2020, Zhou et al., 2011).

A major advantage of the nfP2X7-M CAR is its potential broad specificity against a wide range of cancers. In total, nfP2X7-M CAR-T cells were tested for in vitro cytotoxicity against twenty-four different 
cell lines derived from twelve cancer types, resulting in varying degrees of cytotoxicity against each of the different cancer cell lines tested.

Wetested nfP2X7-M CAR-T cells against two triple-negative breast cancer cell lines MDA-MB-231 and BT549. MDA-MB-231 cells are highly aggressive and model triple-negative breast cancers associated with lower survival rates, while BT549 are considered less agressive. While significant cytotoxicity was observed against both BT549 and MDA-MB-231 cells, CAR-T cells elicited higher cytotoxicity against BT549 than MDA-MB-231 at all E:T ratios tested. This was accompanied by increased cytotoxicity of BT549 cells with the untransduced control, suggesting this cell line is more susceptible to non-antigenspecific T cell-mediated killing. Both P2X7 and nfP2X7 are reported to be expressed in ovarian cancer (Barden JA, 2014, Gilbert et al., 2019). In keeping with this, the nfP2X7-M CAR-T cells showed significant cytotoxicity against two different ovarian cancer cell lines; OVCAR5 and OVCAR-3 in vitro.

We observed no cytotoxicity against three cell lines (multiple myeloma RPMI-8226, leukemia K562 and neuroblastoma SK-ND-Z). Indeed, a separate study demonstrated RPMI-8226 cells are nfP2X7-negative following staining with a monoclonal antibody specific for the E200 epitope of nfP2X7 (Gilbert et al., 2019). The lack of cytotoxicity for the K562 and SK-ND-Z is also likely due to decreased antigen density, but as an nfP2X7-specific antibody is currently not commercially available, we were unable to measure nfP2X7 levels in the different cancer cell lines tested in this study. However, our data are consistent with previous antibody-based studies examining nfP2X7 and P2X7 levels and functional status in several cell lines (Lara et al., 2020, Gilbert et al., 2019). Gilbert et al (2019) examined P2X7 and nfP2X7 levels in a number of cancer cell lines using ion transport as a measurement of pore function for P2X7 and flow cytometric analysis to assess nfP2X7 expression. This study showed PC3 (prostate) and Kelly (neuroblastoma) cell lines expressed nfP2X7 and low levels of P2X7, whereas SK-MEL-5 (melanoma) expressed high levels of P2X7 and low levels of nfP2X7, highlighting a generally inverse relationship between P2X7 and nfP2X7 surface expression. This is with the exception of the Ramos lymphoma cell line, which showed an absence of both nfP2X7 and P2X7 expression (Gilbert et al., 2019). Our cytotoxicity assays were largely consistent with those observations, with statistically significant cytolytoxicity observed against PC3 and Kelly cell lines ( $60 \%$ and $45 \%$ cytolysis above the UT control). Furthermore, we could not detect significant activity against the Ramos or SK-MEL-5 cell lines. P2X7 was reported to be highly expressed in neuroblastoma primary tumours and cell lines (Raffaghello et al., 2006), but we only observed high cytotoxicity against the Be(2)-M17, Kelly and SH-SY5Y cells lines and not SK-ND-Z. Aside from the potential absence of nfP2X7 expression, it is also possible that the SK-ND-Z cells express a different form of nfP2X7, and the epitope targeted by nfP2X7-M CAR-T cells is not present on this non-functional form of the receptor. Furthermore, point mutations, SNPs, splice variants and posttranslational modifications of P2X7 that impair pore formation have been reported (Gilbert et al., 2019, Worthington et al., 2002). and specific mutations of P2X7 are known to be positively selected on transformed cells (Sluyter and Stokes, 2011). However, based on those previous studies overall, it is likely that the variation in anti-tumour efficacies observed in the present study reflects differences in antigen density and/or heterogeneity of nfP2X7 expression under in vitro culture conditions. Taken together, the results from these in vitro experiments combined with previous studies which reported nfP2X7 expression 
on a diverse range of malignant cells indicate that nfP2X7-M CAR T cells are broad acting and specifically respond to nfP2X7 but not wild type $\mathrm{P} 2 \mathrm{X} 7$ on the cell surface.

Encouraged by the cytotoxic activity against multiple cancer cell lines in vitro, we next assessed the clinical utility of nfP2X7-targeting CAR-T cells in pre-clinical in vivo modelling using two well-established xenograft models. These in vivo models are critical for demonstrating a path to clinical utility as they impose a significant selection pressure on the CAR-T cell trafficking to the tumour and binding to the target epitope on the cancer cells. To test the in vivo anti-tumour efficacy of nfP2X7 CAR-T cells, we utilized the MDA-MB-231 breast cancer and PC3 prostate cancer xenograft models, as these cancers represent two of most common types of solid tumours. NfP2X7 has been reported to be expressed on maligant cells in breast cancer patients (Gilbert et al., 2019). Furthermore, Slater et al (2004a) showed that human prostate cancer biopsies express the nfP2X7 receptor and an increase in expression is associated with cancer progression (Slater et al., 2004, Barden et al., 2016). In the present study, preclinical testing of nfP2X7-targeting CAR-T cells demonstrated significant inhibition of tumour growth for both breast cancer and prostate cancer.

In six independent experiments in the PC3 prostate cancer xenograft model, we consistently observed significant tumour inhibition in mice administered nfP2X7-targeting CAR-T cells compared to mice administered untransduced T cells. In one experiment, we observed $100 \%$ survival of nfP2X7-M CAR-T cell-treated mice up to 90 days post-tumour inoculation (Supplementary Figure 10). The efficacy in the PC3 model was associated with significant CAR-T cell intratumoural infiltration. A similar but less potent effect on tumour inhibition was observed in the MDA-MB-231 breast cancer xenograft model. Indeed, separate studies which have administered CAR-T cells into the MDA-MB-231 model demonstrate only modest tumour inhibition of highly aggressive tumours (Han et al., 2018, Song et al., 2016, Wei et al., 2018). However, more recent work in the MDA-MB-231 model has achieved significant tumour inhibition and improved survival using CAR-T cells directed towards ICAM-1 (Wei et al., 2020). In the results presented in this study, the majority of tumour-infiltrating CAR-T cells were of a $T_{E M}$ or $T_{E F F}$ subset phenotype and acquired the expression of co-inhibitory receptors. This dramatic change in $\mathrm{T}$ cell phenotype compared with phenotypes at pre-injection is indicative of the T cells undergoing chronic activation in the tumour microenvironment.

The observed differences in efficacy between the MDA-MB-231 and PC3 models could be due to a number of factors, including differences in levels of antigen expression, differences in the percentage of tumour cells expressing the antigen, or differences in the ability of the tumours and the associated tumour microenvironment to limit CAR-T cell recruitment or suppress CAR-T cell function. From our in vitro data, it appears that PC3 cells are more susceptible to nfP2X7-M CAR-T cell-mediated cytotoxicity than MDA-MB-231 cells, potentially due to a higher level of antigen expression per cell or a greater frequency of cells expressing sufficient antigen. Loss of antigen expression has been reported as a mechanism for the development of resistance to the CAR-T cell treatment (Song et al., 2019) and loss of nfP2X7 expression, which may have occurred in in MDA-MB-231 tumours, may have also contributed to the differences in tumour susceptibility to nfP2X7-targeting CAR-T cells in vivo. While this research paves 
the way for initial clinical studies in humans, the availability of a high specificity nfP2X7-specific monoclonal antibody is crucial in order to screen patients for tumour expression of nfP2X7 to identify those patients who will most likely benefit from nfP2X7-targeting CAR-T cell therapy.

In summary, our results clearly highlight the potential of nfP2X7-M targeting CAR-T cells as a novel immunotherapy for multiple solid cancer types. This study report the first evidence that targeting nfP2X7 has great potential as an immunotherapy for a broad range of nfP2X7 expressing solid tumours, and that the CAR-T cell modality may provide a functional alternative to targeting nfP2X7 with a monoclonal antibody (Gilbert et al., 2017). Further approaches to improve the efficacy of nfP2X7-targeting CAR-T cells may involve administration in combination with standard surgical and/or chemotherapy regimens, or with checkpoint inhibitors. The efficacy of nfP2X7-targeting CAR-T cells, either alone or in combination with other therapies will need to be tested in clinical trials after stratification of participants with nfP2X7positive tumours. Despite this, results presented in this study position nfP2X7 as a promising target for CAR-T cell therapy, overcoming a major challenge in the identification of a suitable target antigen for immunotherapy and providing a potential avenue to translate the success of CAR-T cell therapies from haematological malignancies to a broad range of solid cancers.

\section{References}

AGARWAL, S., HANAUER, J. D. S., FRANK, A. M., RIECHERT, V., THALHEIMER, F. B. \& BUCHHOLZ, C. J. 2020. In Vivo Generation of CAR T Cells Selectively in Human CD4(+) Lymphocytes. Mol Ther, 28, 17831794.

ALIZADEH, D., WONG, R. A., YANG, X., WANG, D., PECORARO, J. R., KUO, C. F., AGUILAR, B., QI, Y., ANN, D. K., STARR, R., URAK, R., WANG, X., FORMAN, S. J. \& BROWN, C. E. 2019. IL15 Enhances CAR-T Cell Antitumor Activity by Reducing mTORC1 Activity and Preserving Their Stem Cell Memory Phenotype. Cancer Immunol Res, 7, 759-772.

BARDEN, J. A., GIDLEY-BAIRD, A., TEH, L. C., RAJASEKARIAH, G., PEDERSEN, J., CHRISTENSEN, N. I., SPIELMAN, D. \& ASHLEY, D. M. 2016. Therapeutic Targeting of the Cancer-Specific Cell Surface Biomarker nfP2X7. Journal of Clinical \& Cellular Immunology, 7.

BARDEN JA, Y. A., PEDERSEN J, DANIELETTO S, DELPRADO W 2014. Non-Functional P2X7: A Novel and Ubiquitous Target in Human Cancer. J Clin Cell Immunol 5.

BARRY, S. C., HARDER, B., BRZEZINSKI, M., FLINT, L. Y., SEPPEN, J. \& OSBORNE, W. R. 2001. Lentivirus vectors encoding both central polypurine tract and posttranscriptional regulatory element provide enhanced transduction and transgene expression. Hum Gene Ther, 12, 1103-8.

BARRY, S. C., SEPPEN, J., RAMESH, N., FOSTER, J. L., SEYAMA, K., OCHS, H. D., GARCIA, J. V. \& OSBORNE, W. R. 2000. Lentiviral and murine retroviral transduction of T cells for expression of human CD40 ligand. Hum Gene Ther, 11, 323-32. 
BAUMGAERTNER, P., SPEISER, D. E., ROMERO, P., RUFER, N. \& HEBEISEN, M. 2016. Chromium-51 (51Cr) Release Assay to Assess Human T Cells for Functional Avidity and Tumor Cell Recognition. Bio-protocol, 6, e1906.

BIASCO, L., IZOTOVA, N., RIVAT, C., GHORASHIAN, S., RICHARDSON, R., GUVENEL, A., HOUGH, R., WYNN, R., POPOVA, B., LOPES, A., PULE, M., THRASHER, A. J. \& AMROLIA, P. J. 2021. Clonal expansion of T memory stem cells determines early anti-leukemic responses and long-term CAR T cell persistence in patients. Nat Cancer, 2, 629-642.

BLAESCHKE, F., STENGER, D., KAEUFERLE, T., WILLIER, S., LOTFI, R., KAISER, A. D., ASSENMACHER, M., DORING, M., FEUCHT, J. \& FEUCHTINGER, T. 2018. Induction of a central memory and stem cell memory phenotype in functionally active CD4(+) and CD8(+) CAR T cells produced in an automated good manufacturing practice system for the treatment of CD19(+) acute lymphoblastic leukemia. Cancer Immunol Immunother, 67, 1053-1066.

BRENTJENS, R. J., RIVIERE, I., PARK, J. H., DAVILA, M. L., WANG, X., STEFANSKI, J., TAYLOR, C., YEH, R., BARTIDO, S., BORQUEZ-OJEDA, O., OLSZEWSKA, M., BERNAL, Y., PEGRAM, H., PRZYBYLOWSKI, M., HOLLYMAN, D., USACHENKO, Y., PIRRAGLIA, D., HOSEY, J., SANTOS, E., HALTON, E., MASLAK, P., SCHEINBERG, D., JURCIC, J., HEANEY, M., HELLER, G., FRATTINI, M. \& SADELAIN, M. 2011. Safety and persistence of adoptively transferred autologous CD19-targeted T cells in patients with relapsed or chemotherapy refractory B-cell leukemias. Blood, 118, 4817-28.

BUSCH, D. H., FRASSLE, S. P., SOMMERMEYER, D., BUCHHOLZ, V. R. \& RIDDELL, S. R. 2016. Role of memory T cell subsets for adoptive immunotherapy. Semin Immunol, 28, 28-34.

CIERI, N., CAMISA, B., COCCHIARELLA, F., FORCATO, M., OLIVEIRA, G., PROVASI, E., BONDANZA, A., BORDIGNON, C., PECCATORI, J., CICERI, F., LUPO-STANGHELLINI, M. T., MAVILIO, F., MONDINO, A., BICCIATO, S., RECCHIA, A. \& BONINI, C. 2013. IL-7 and IL-15 instruct the generation of human memory stem $\mathrm{T}$ cells from naive precursors. Blood, 121, 573-84.

DAGOGO-JACK, I. \& SHAW, A. T. 2018. Tumour heterogeneity and resistance to cancer therapies. Nat Rev Clin Oncol, 15, 81-94.

DENG, Z., WU, Y., MA, W., ZHANG, S. \& ZHANG, Y. Q. 2015. Adoptive T-cell therapy of prostate cancer targeting the cancer stem cell antigen EpCAM. BMC Immunol, 16, 1.

GARGETT, T. \& BROWN, M. P. 2015. Different cytokine and stimulation conditions influence the expansion and immune phenotype of third-generation chimeric antigen receptor $\mathrm{T}$ cells specific for tumor antigen GD2. Cytotherapy, 17, 487-95.

GARGETT, T., TRUONG, N., EBERT, L. M., YU, W. \& BROWN, M. P. 2019. Optimization of manufacturing conditions for chimeric antigen receptor $T$ cells to favor cells with a central memory phenotype.

Cytotherapy, 21, 593-602. 
GATTINONI, L., LUGLI, E., JI, Y., POS, Z., PAULOS, C. M., QUIGLEY, M. F., ALMEIDA, J. R., GOSTICK, E., YU, Z., CARPENITO, C., WANG, E., DOUEK, D. C., PRICE, D. A., JUNE, C. H., MARINCOLA, F. M., ROEDERER, M. \& RESTIFO, N. P. 2011. A human memory T cell subset with stem cell-like properties. Nat Med, 17, $1290-7$.

GILBERT, S. M., GIDLEY BAIRD, A., GLAZER, S., BARDEN, J. A., GLAZER, A., TEH, L. C. \& KING, J. 2017. A phase I clinical trial demonstrates that nfP2X7 -targeted antibodies provide a novel, safe and tolerable topical therapy for basal cell carcinoma. Br J Dermatol, 177, 117-124.

GILBERT, S. M., OLIPHANT, C. J., HASSAN, S., PEILLE, A. L., BRONSERT, P., FALZONI, S., DI VIRGILIO, F., MCNULTY, S. \& LARA, R. 2019. ATP in the tumour microenvironment drives expression of nfP2X7, a key mediator of cancer cell survival. Oncogene, 38, 194-208.

GOLUBOVSKAYA, V. \& WU, L. 2016. Different Subsets of T Cells, Memory, Effector Functions, and CAR-T Immunotherapy. Cancers (Basel), 8.

GU, B. J., ZHANG, W. Y., BENDALL, L. J., CHESSELL, I. P., BUELL, G. N. \& WILEY, J. S. 2000. Expression of P2X(7) purinoceptors on human lymphocytes and monocytes: evidence for nonfunctional P2X(7) receptors. Am J Physiol Cell Physiol, 279, C1189-97.

GUEST, R. D., HAWKINS, R. E., KIRILLOVA, N., CHEADLE, E. J., ARNOLD, J., O'NEILL, A., IRLAM, J., CHESTER, K. A., KEMSHEAD, J. T., SHAW, D. M., EMBLETON, M. J., STERN, P. L. \& GILHAM, D. E. 2005. The role of extracellular spacer regions in the optimal design of chimeric immune receptors: evaluation of four different scFvs and antigens. J Immunother, 28, 203-11.

HAN, Y., XIE, W., SONG, D. G. \& POWELL, D. J., JR. 2018. Control of triple-negative breast cancer using ex vivo self-enriched, costimulated NKG2D CAR T cells. J Hematol Oncol, 11, 92.

HOU, B., TANG, Y., LI, W., ZENG, Q. \& CHANG, D. 2019. Efficiency of CAR-T Therapy for Treatment of Solid Tumor in Clinical Trials: A Meta-Analysis. Dis Markers, 2019, 3425291.

HUDECEK, M., SOMMERMEYER, D., KOSASIH, P. L., SILVA-BENEDICT, A., LIU, L., RADER, C., JENSEN, M. C. \& RIDDELL, S. R. 2015. The nonsignaling extracellular spacer domain of chimeric antigen receptors is decisive for in vivo antitumor activity. Cancer Immunol Res, 3, 125-35.

HURTON, L. V., SINGH, H., NAJJAR, A. M., SWITZER, K. C., MI, T., MAITI, S., OLIVARES, S., RABINOVICH, B., HULS, H., FORGET, M. A., DATAR, V., KEBRIAEI, P., LEE, D. A., CHAMPLIN, R. E. \& COOPER, L. J. 2016. Tethered IL-15 augments antitumor activity and promotes a stem-cell memory subset in tumor-specific $T$ cells. Proc Natl Acad Sci U S A, 113, E7788-E7797.

IRVING, M., VUILLEFROY DE SILLY, R., SCHOLTEN, K., DILEK, N. \& COUKOS, G. 2017. Engineering Chimeric Antigen Receptor T-Cells for Racing in Solid Tumors: Don't Forget the Fuel. Front Immunol, 8, 267.

JENSEN, M. C. \& RIDDELL, S. R. 2015. Designing chimeric antigen receptors to effectively and safely target tumors. Curr Opin Immunol, 33, 9-15. 
KOCHENDERFER, J. N., WILSON, W. H., JANIK, J. E., DUDLEY, M. E., STETLER-STEVENSON, M., FELDMAN, S. A., MARIC, I., RAFFELD, M., NATHAN, D. A., LANIER, B. J., MORGAN, R. A. \& ROSENBERG, S. A. 2010. Eradication of $B$-lineage cells and regression of lymphoma in a patient treated with autologous $T$ cells genetically engineered to recognize CD19. Blood, 116, 4099-102.

LARA, R., ADINOLFI, E., HARWOOD, C. A., PHILPOTT, M., BARDEN, J. A., DI VIRGILIO, F. \& MCNULTY, S. 2020. P2X7 in Cancer: From Molecular Mechanisms to Therapeutics. Front Pharmacol, 11, 793.

LIU, J., ZHANG, S., HU, Y., YANG, Z., LI, J., LIU, X., DENG, L., WANG, Y., ZHANG, X., JIANG, T. \& LU, X. 2016. Targeting PD-1 and Tim-3 Pathways to Reverse CD8 T-Cell Exhaustion and Enhance Ex Vivo T-Cell Responses to Autologous Dendritic/Tumor Vaccines. J Immunother, 39, 171-80.

LYNN, R. C., WEBER, E. W., SOTILLO, E., GENNERT, D., XU, P., GOOD, Z., ANBUNATHAN, H., LATTIN, J., JONES, R., TIEU, V., NAGARAJA, S., GRANJA, J., DE BOURCY, C. F. A., MAJZNER, R., SATPATHY, A. T., QUAKE, S. R., MONJE, M., CHANG, H. Y. \& MACKALL, C. L. 2019. c-Jun overexpression in CAR T cells induces exhaustion resistance. Nature, 576, 293-300.

MAUDE, S. L., LAETSCH, T. W., BUECHNER, J., RIVES, S., BOYER, M., BITTENCOURT, H., BADER, P., VERNERIS, M. R., STEFANSKI, H. E., MYERS, G. D., QAYED, M., DE MOERLOOSE, B., HIRAMATSU, H., SCHLIS, K., DAVIS, K. L., MARTIN, P. L., NEMECEK, E. R., YANIK, G. A., PETERS, C., BARUCHEL, A., BOISSEL, N., MECHINAUD, F., BALDUZZI, A., KRUEGER, J., JUNE, C. H., LEVINE, B. L., WOOD, P., TARAN, T., LEUNG, M., MUELLER, K. T., ZHANG, Y., SEN, K., LEBWOHL, D., PULSIPHER, M. A. \& GRUPP, S. A. 2018.

Tisagenlecleucel in Children and Young Adults with B-Cell Lymphoblastic Leukemia. N Engl J Med, 378, 439-448.

MCBRIDE, J. A. \& STRIKER, R. 2017. Imbalance in the game of T cells: What can the CD4/CD8 T-cell ratio tell us about HIV and health? PLoS Pathog, 13, e1006624.

MINN, A. J., GUPTA, G. P., SIEGEL, P. M., BOS, P. D., SHU, W., GIRI, D. D., VIALE, A., OLSHEN, A. B., GERALD, W. L. \& MASSAGUE, J. 2005. Genes that mediate breast cancer metastasis to lung. Nature, 436, 518-24.

MOELLER, M., HAYNES, N. M., KERSHAW, M. H., JACKSON, J. T., TENG, M. W., STREET, S. E., CERUTTI, L., JANE, S. M., TRAPANI, J. A., SMYTH, M. J. \& DARCY, P. K. 2005. Adoptive transfer of gene-engineered CD4+ helper T cells induces potent primary and secondary tumor rejection. Blood, 106, 2995-3003.

PARK, J. H., RIVIERE, I., GONEN, M., WANG, X., SENECHAL, B., CURRAN, K. J., SAUTER, C., WANG, Y., SANTOMASSO, B., MEAD, E., ROSHAL, M., MASLAK, P., DAVILA, M., BRENTJENS, R. J. \& SADELAIN, M. 2018. Long-Term Follow-up of CD19 CAR Therapy in Acute Lymphoblastic Leukemia. N Engl J Med, 378, 449-459.

PASZKIEWICZ, P. J., FRASSLE, S. P., SRIVASTAVA, S., SOMMERMEYER, D., HUDECEK, M., DREXLER, I., SADELAIN, M., LIU, L., JENSEN, M. C., RIDDELL, S. R. \& BUSCH, D. H. 2016. Targeted antibody-mediated depletion of murine CD19 CAR T cells permanently reverses B cell aplasia. J Clin Invest, 126, 4262-4272. 
PORTER, D. L., HWANG, W. T., FREY, N. V., LACEY, S. F., SHAW, P. A., LOREN, A. W., BAGG, A., MARCUCCI, K. T., SHEN, A., GONZALEZ, V., AMBROSE, D., GRUPP, S. A., CHEW, A., ZHENG, Z., MILONE, M. C., LEVINE, B. L., MELENHORST, J. J. \& JUNE, C. H. 2015. Chimeric antigen receptor T cells persist and induce sustained remissions in relapsed refractory chronic lymphocytic leukemia. Sci Trans/ Med, 7, 303ra139.

PORTER, D. L., LEVINE, B. L., KALOS, M., BAGG, A. \& JUNE, C. H. 2011. Chimeric antigen receptor-modified T cells in chronic lymphoid leukemia. N Engl J Med, 365, 725-33.

RAFFAGHELLO, L., CHIOZZI, P., FALZONI, S., DI VIRGILIO, F. \& PISTOIA, V. 2006. The P2X7 receptor sustains the growth of human neuroblastoma cells through a substance P-dependent mechanism. Cancer Res, 66, 907-14.

SABATINO, M., HU, J., SOMMARIVA, M., GAUTAM, S., FELLOWES, V., HOCKER, J. D., DOUGHERTY, S., QIN, H., KLEBANOFF, C. A., FRY, T. J., GRESS, R. E., KOCHENDERFER, J. N., STRONCEK, D. F., JI, Y. \& GATTINONI, L. 2016. Generation of clinical-grade CD19-specific CAR-modified CD8+ memory stem cells for the treatment of human B-cell malignancies. Blood, 128, 519-28.

SAVIO, L. E. B., DE ANDRADE MELLO, P., DA SILVA, C. G. \& COUTINHO-SILVA, R. 2018. The P2X7 Receptor in Inflammatory Diseases: Angel or Demon? Front Pharmacol, 9, 52.

SAWADA, M., GOTO, K., MORIMOTO-OKAZAWA, A., HARUNA, M., YAMAMOTO, K., YAMAMOTO, Y., NAKAGAWA, S., HIRAMATSU, K., MATSUZAKI, S., KOBAYASHI, E., KAWASHIMA, A., HIRATA, M., IWAHORI, K., KIMURA, T., UEDA, Y., KIMURA, T. \& WADA, H. 2020. PD-1+ Tim3+ tumor-infiltrating CD8 T cells sustain the potential for IFN-gamma production, but lose cytotoxic activity in ovarian cancer. Int Immunol, 32, 397-405.

SCHMUECK-HENNERESSE, M., OMER, B., SHUM, T., TASHIRO, H., MAMONKIN, M., LAPTEVA, N., SHARMA, S., ROLLINS, L., DOTTI, G., REINKE, P., VOLK, H. D. \& ROONEY, C. M. 2017. Comprehensive Approach for Identifying the T Cell Subset Origin of CD3 and CD28 Antibody-Activated Chimeric Antigen ReceptorModified T Cells. J Immunol, 199, 348-362.

SCHNEIDER, D., XIONG, Y., WU, D., HU, P., ALABANZA, L., STEIMLE, B., MAHMUD, H., ANTHONY-GONDA, K., KRUEGER, W., ZHU, Z., DIMITROV, D. S., ORENTAS, R. J. \& DROPULIC, B. 2021. Trispecific CD19-CD20CD22-targeting duoCAR-T cells eliminate antigen-heterogeneous B cell tumors in preclinical models. Sci Transl Med, 13.

SINGER, M., WANG, C., CONG, L., MARJANOVIC, N. D., KOWALCZYK, M. S., ZHANG, H., NYMAN, J., SAKUISHI, K., KURTULUS, S., GENNERT, D., XIA, J., KWON, J. Y. H., NEVIN, J., HERBST, R. H., YANAI, I., ROZENBLATT-ROSEN, O., KUCHROO, V. K., REGEV, A. \& ANDERSON, A. C. 2016. A Distinct Gene Module for Dysfunction Uncoupled from Activation in Tumor-Infiltrating T Cells. Cell, 166, 1500-1511 e9.

SLATER, M., DANIELETTO, S., GIDLEY-BAIRD, A., TEH, L. C. \& BARDEN, J. A. 2004. Early prostate cancer detected using expression of non-functional cytolytic P2X7 receptors. Histopathology, 44, 206-15. 
SLUYTER, R. \& STOKES, L. 2011. Significance of P2X7 receptor variants to human health and disease. Recent Pat DNA Gene Seq, 5, 41-54.

SOMMERMEYER, D., HUDECEK, M., KOSASIH, P. L., GOGISHVILI, T., MALONEY, D. G., TURTLE, C. J. \& RIDDELL, S. R. 2016. Chimeric antigen receptor-modified T cells derived from defined CD8+ and CD4+ subsets confer superior antitumor reactivity in vivo. Leukemia, 30, 492-500.

SONG, D. G., YE, Q., POUSSIN, M., CHACON, J. A., FIGINI, M. \& POWELL, D. J., JR. 2016. Effective adoptive immunotherapy of triple-negative breast cancer by folate receptor-alpha redirected CAR T cells is influenced by surface antigen expression level. $J$ Hematol Oncol, 9, 56.

SONG, M. K., PARK, B. B. \& UHM, J. E. 2019. Resistance Mechanisms to CAR T-Cell Therapy and Overcoming Strategy in B-Cell Hematologic Malignancies. Int J Mol Sci, 20.

SUNG, H., FERLAY, J., SIEGEL, R. L., LAVERSANNE, M., SOERJOMATARAM, I., JEMAL, A. \& BRAY, F. 2021. Global Cancer Statistics 2020: GLOBOCAN Estimates of Incidence and Mortality Worldwide for 36 Cancers in 185 Countries. CA Cancer J Clin, 71, 209-249.

SURPRENANT, A., RASSENDREN, F., KAWASHIMA, E., NORTH, R. A. \& BUELL, G. 1996. The cytolytic P2Z receptor for extracellular ATP identified as a P2X receptor (P2X7). Science, 272, 735-8.

TERAKURA, S., YAMAMOTO, T. N., GARDNER, R. A., TURTLE, C. J., JENSEN, M. C. \& RIDDELL, S. R. 2012. Generation of CD19-chimeric antigen receptor modified CD8+ T cells derived from virus-specific central memory T cells. Blood, 119, 72-82.

TURTLE, C. J., HANAFI, L. A., BERGER, C., GOOLEY, T. A., CHERIAN, S., HUDECEK, M., SOMMERMEYER, D., MELVILLE, K., PENDER, B., BUDIARTO, T. M., ROBINSON, E., STEEVENS, N. N., CHANEY, C., SOMA, L., CHEN, X., YEUNG, C., WOOD, B., LI, D., CAO, J., HEIMFELD, S., JENSEN, M. C., RIDDELL, S. R. \& MALONEY, D. G. 2016. CD19 CAR-T cells of defined CD4+:CD8+ composition in adult B cell ALL patients. J Clin Invest, 126, 2123-38.

WANG, D., AGUILAR, B., STARR, R., ALIZADEH, D., BRITO, A., SARKISSIAN, A., OSTBERG, J. R., FORMAN, S. J. \& BROWN, C. E. 2018. Glioblastoma-targeted CD4+ CAR T cells mediate superior antitumor activity. JCl Insight, 3.

WANG, X., CHANG, W. C., WONG, C. W., COLCHER, D., SHERMAN, M., OSTBERG, J. R., FORMAN, S. J., RIDDELL, S. R. \& JENSEN, M. C. 2011. A transgene-encoded cell surface polypeptide for selection, in vivo tracking, and ablation of engineered cells. Blood, 118, 1255-63.

WANG, X., NARANJO, A., BROWN, C. E., BAUTISTA, C., WONG, C. W., CHANG, W. C., AGUILAR, B., OSTBERG, J. R., RIDDELL, S. R., FORMAN, S. J. \& JENSEN, M. C. 2012. Phenotypic and functional attributes of lentivirus-modified CD19-specific human CD8+ central memory T cells manufactured at clinical scale. $J$ Immunother, 35, 689-701. 
WATANABE, N., BAJGAIN, P., SUKUMARAN, S., ANSARI, S., HESLOP, H. E., ROONEY, C. M., BRENNER, M. K., LEEN, A. M. \& VERA, J. F. 2016. Fine-tuning the CAR spacer improves T-cell potency. Oncoimmunology, 5, e1253656.

WEI, H., WANG, Z., KUANG, Y., WU, Z., ZHAO, S., ZHANG, Z., LI, H., ZHENG, M., ZHANG, N., LONG, C., GUO, W., NIE, C., YANG, H. \& TONG, A. 2020. Intercellular Adhesion Molecule-1 as Target for CAR-T-Cell Therapy of Triple-Negative Breast Cancer. Front Immunol, 11, 573823.

WEI, J., SUN, H., ZHANG, A., WU, X., LI, Y., LIU, J., DUAN, Y., XIAO, F., WANG, H., LV, M., WANG, L. \& WU, C. 2018. A novel $A X L$ chimeric antigen receptor endows $T$ cells with anti-tumor effects against triple negative breast cancers. Cell Immunol, 331, 49-58.

WORTHINGTON, R. A., SMART, M. L., GU, B. J., WILLIAMS, D. A., PETROU, S., WILEY, J. S. \& BARDEN, J. A. 2002. Point mutations confer loss of ATP-induced human P2X(7) receptor function. FEBS Lett, 512, 43-6.

XU, Y., ZHANG, M., RAMOS, C. A., DURETT, A., LIU, E., DAKHOVA, O., LIU, H., CREIGHTON, C. J., GEE, A. P., HESLOP, H. E., ROONEY, C. M., SAVOLDO, B. \& DOTTI, G. 2014. Closely related T-memory stem cells correlate with in vivo expansion of CAR.CD19-T cells and are preserved by IL-7 and IL-15. Blood, 123, 3750-9.

YANG, Y., KOHLER, M. E., CHIEN, C. D., SAUTER, C. T., JACOBY, E., YAN, C., HU, Y., WANHAINEN, K., QIN, H. \& FRY, T. J. 2017. TCR engagement negatively affects CD8 but not CD4 CAR T cell expansion and leukemic clearance. Sci Transl Med, 9.

ZHANG, C., WANG, Z., YANG, Z., WANG, M., LI, S., LI, Y., ZHANG, R., XIONG, Z., WEI, Z., SHEN, J., LUO, Y., ZHANG, Q., LIU, L., QIN, H., LIU, W., WU, F., CHEN, W., PAN, F., ZHANG, X., BIE, P., LIANG, H., PECHER, G. \& QIAN, C. 2017. Phase I Escalating-Dose Trial of CAR-T Therapy Targeting CEA(+) Metastatic Colorectal Cancers. Mol Ther, 25, 1248-1258.

ZHANG, H., ZHAO, P. \& HUANG, H. 2020. Engineering better chimeric antigen receptor T cells. Exp Hematol Oncol, 9, 34.

ZHAO, Z., CONDOMINES, M., VAN DER STEGEN, S. J. C., PERNA, F., KLOSS, C. C., GUNSET, G., PLOTKIN, J. \& SADELAIN, M. 2015. Structural Design of Engineered Costimulation Determines Tumor Rejection Kinetics and Persistence of CAR T Cells. Cancer Cell, 28, 415-428.

ZHOU, Q., MUNGER, M. E., VEENSTRA, R. G., WEIGEL, B. J., HIRASHIMA, M., MUNN, D. H., MURPHY, W. J., AZUMA, M., ANDERSON, A. C., KUCHROO, V. K. \& BLAZAR, B. R. 2011. Coexpression of Tim-3 and PD-1 identifies a CD8+ T-cell exhaustion phenotype in mice with disseminated acute myelogenous leukemia. Blood, 117, 4501-10.

ZOU, F., LU, L., LIU, J., XIA, B., ZHANG, W., HU, Q., LIU, W., ZHANG, Y., LIN, Y., JING, S., HUANG, M., HUANG, B., LIU, B. \& ZHANG, H. 2019. Engineered triple inhibitory receptor resistance improves anti-tumor CAR-T 
cell performance via CD56. Nat Commun, 10, 4109.

ZUCCOLOTTO, G., FRACASSO, G., MERLO, A., MONTAGNER, I. M., RONDINA, M., BOBISSE, S., FIGINI, M., CINGARLINI, S., COLOMBATTI, M., ZANOVELLO, P. \& ROSATO, A. 2014. PSMA-specific CAR-engineered T cells eradicate disseminated prostate cancer in preclinical models. PLoS One, 9, e109427.

\section{Figures}

\section{Figure 1}

Impact of the hinge length on cytotoxicity potential of nfP2X7-CAR-T cells A) Schematic of the lentiviral vector construct with EF1a promoter followed by the leader sequence, nfP2X7 antigen binding domain, hinge region (short, medium or long), CD28 transmembrane domain, 41BB, CD3 zeta, T2A and EGFRt. B) Flow cytometric analysis of CAR expression in CD4+/CD8+ compartments on the three different CAR-T cells (nfP2X7-S, nfP2X7-M and nfP2X7-L) by EGFR staining. C) Specific cytotoxicity of target cells by CD8+ nfP2X7-CAR-T cells with three different hinge lengths (nfP2X7-S, nfP2X7-M and nfP2X7-L) compared with CD8+ untransduced (UT) cells. Target cell lines include: K562 (leukemia), MDA-MB-231 (breast cancer), U87 (glioma), M21 (melanoma) and SK-ND-Z (neuroblastoma). K562 transduced to express OKT3 was included as a positive control. CAR-T cells were co-cultured with target cancer cell lines at E:T ratios of 30:1, 10:1, 3:1 and 1:1 for $4 \mathrm{~h}$. Specific cytotoxicity was measured using a chromium51 release cytotoxicity assay. Pooled data from two independent experiments. D) Cytokine release assay for nfP2X7-CAR-T cells. CD4+ CAR-T cells and target cells were co-cultured for $24 \mathrm{~h}$ and the concentration of IL-2, IFN- $\$ and TNF-a in the supernatant was measured using the Bio-Plex system. Cytokines produced by untransduced CD4+ cells were compared with nfP2X7-CAR-T cells harbouring different hinge lengths. Target cell lines include: K562, K562-OKT3, MDA-MB-231, U87 and SK-ND-Z. Data represent two independent experiments.

\section{Figure 2}

NfP2X7-CAR-T cells consist of mostly naïve and central memory phenotypes and exhibit broad-spectrum cytotoxicity against a diverse range of cancer cells. A) Frequency of EGFR reporter expression on total $\mathrm{CD} 3+$ cells 7 days post-transduction, ratio of $\mathrm{CD} 8+/ \mathrm{CD} 4+$ of $C D 3+$ end of expansion on d14 post-PBMC; $n$ $=10$. B) Representative FACS plots for CD45RA+, CD62L+ and CCR7+ expression of CD4+ and CD8+ nfP2X7-M CAR-Tcells at end of expansion on d14 post-PBMC. Frequency of TNaive, TCM, TEM and TEMRA populations based on CD45RA+ and CD62L+ expression; $n=7$. C) Cytotoxicity of target cells by CD3+ nfP2X7-M-CAR-T cells compared with donor-matched untransduced (UT) cells generated in parallel . Target cell lines include: PC3 (prostate cancer), C32 (melanoma), Sk-Mel-5 (melanoma), Sk-Mel-28 (melanoma), MDA-MB-231 (breast cancer), Be(2)-M17 (neuroblastoma), Raji (lymphoma), RD 
(rhabdomyosarcoma), AsPC-1 (pancreatic cancer), OV90 (ovarian cancer), UM-SCC-1 (head and neck carcinoma), OVCAR3 (ovarian cancer), Namalwa (lymphoma), Ramos (lymphoma), RPMI-8226 (myeloma), LIM1215 (colorectal cancer), PC9 (lung cancer), NC1-H460 (lung cancer), Kelly (neuroblastoma), SH-SY5Y (neuroblastoma). CAR-T cells were co-cultured with target cancer cell lines at E:T ratios of 10:1, 3:1 and 1:1 for $16 \mathrm{~h}$. Specific cytotoxicity was measured using a BrightGlo luciferasebased cytotoxicity assay system; paired T test comparing the nfP2X7-M CAR-T with CD3+ UT at the indicated time points. ${ }^{\star *} P \leq 0.01,{ }^{\star} * * P \leq 0.001,{ }^{\star} * \star * P \leq 0.0001$, Pooled data from three independent experiments. D) Table listing cancer types and cancer cell lines tested. Cytotoxicity values at E:T ratio of 10:1, with cytotoxicity values from untransduced control T cells subtracted. E) Representative graph showing changes in normalised cell index over time (in hours) for the human prostate cancer cell line PC3 when untreated (black) or treated with either untransduced T cells (UT) (dark blue) or nfP2X7-M CAR T cells (orange). Black vertical line reflects time point at which $T$ cells were added. F) The area under the curves were measured and normalised to the cancer cell alone control. Data represebts mean \pm SEM. Data is pooled from six independent experiments for MDA-MB-231 and PC3 target cells lines and four independent experiments for OVCAR3 target cell line, where each dot represents an experiment conducted with $\mathrm{T}$ cells from a separate donor. ${ }^{*}=p<0.05$, paired $\mathrm{T}$ test.

\section{Figure 3}

CAR T cells are readily detected within tumours of NSG mice. A) For intravital microscopy, 2x106 MDAMB-231-LM2 cells expressing GFP were injected into the mammary fat pad of NSG mice and allowed to establish for 2 weeks. The mice then received an intravenous injection of 2x107 CAR T nfP2X7-M cells fluorescently labelled with CellTracker Orange as well as Cy5 Dextran (for visualisation of blood vessels with active blood flow). The surgically exposed tumour was then placed under a 20x objective lens and the interaction between the CAR-T cells and the blood vessels were visualised in real time. Representative images showing CAR-T cells firmly adhered to a blood vessel (left) and a CAR T cell transmigrating across a blood vessel (right). Scale bars $=50 \mu \mathrm{m}$. B) Tumours were fixed in formalin and embedded in paraffin for immunofluorescence. Following antigen retrieval and blocking, tumour sections of $4 \mu \mathrm{m}$ thickness were stained with a primary rabbit anti-human CD3+ antibody, a secondary anti-rabbit AlexaFluor555 antibody and DAPI. Representative images shown with the secondary alone control included as inserts. Scale bars $=50 \mu \mathrm{m}$. The number of CD3+DAPI+ cells were quantified, with groups blinded. Graph shows the average number of CD3+ DAPI+ cells in MDA-MB-231-LM2 tumours ( $n=2$ mice per group) or PC3 tumours ( $n=2$ mice per group) receiving UT or nfP2X7-M CAR-T cells ( $n=2$ independent donors) \pm SD. C) T cell killing was also observed using in vitro real time imaging techniques. MDA-MB231-LM2 cells were seeded into wells and allowed to grow overnight. T cells pulsed with Fluo-4 AM (green) and PI (red) were then added into the wells and images were taken at 10 s intervals for at least 3 hours using a 40x objective lens on the Zeiss LSM700. Representative images shown from two independent experiments 


\section{Figure 4}

NfP2X7-targeting CAR-T cells significantly inhibit the tumourigenesis of a human breast cancer xenograft model. NSG mice were subcutaneously injected with 2x106 MDA-MB-231 human breast cancer cells into the fourth mammary fat pad and intravenously injected with 2x107 nfP2X7-targeting CAR-T cells or untransduced $\mathrm{T}$ cells on $\mathrm{d} 3$ post-tumour injection. Tumours were harvested for flow cytometric analysis at $\mathrm{d} 40$ post-tumour injection. (A) Tumour growth curves (as pooled and individual mice) and tumour weights; $\mathrm{n}=13-15$; tumour size: two-way ANOVA with Bonferroni's post-test, tumour weight: unpaired ttest. (B) Frequency of human CD3+ T cells of total viable cells in tumours, number of human CD3+ T cells per mg of tumour and $C D 4+/ C D 8+$ ratio of $C D 3+; n=6-8$, unpaired t-test. (C) Frequencies of $T$ cell subsets as defined by CD45RO and CD62L expression by intratumoural CD4+ and CD8+ T cells; $n=12-15$, two-way ANOVA with Bonferroni's post-test. (D) Frequency of PD-1, CTLA-4 and LAG-3 expression by intratumoural CD4+ and CD8+ T cells; $n=5-10$. Data in (A, C, D) are pooled from 2 independent experiments following in vivo delivery of 2 independent CAR-T cell preparations derived from 1 healthy donor. Data in (B) representative of a single independent experiment. Data represented as mean $\pm S E M ; * \star p \leq 0.01, \star \star \star$ $p \leq 0.001, * \star \star \star ~ p \leq 0.0001$.

\section{Figure 5}

NfP2X7-targeting CAR-T cells significantly inhibit the tumourigenesis of a human prostate cancer xenograft model. NSG mice were subcutaneously injected with 1x106 PC3 human prostate cancer cells into the lower abdomen and intravenously injected with $2 \times 107 \mathrm{nfP} 2 \times 7$-targeting CAR-T cells or untransduced $\mathrm{T}$ cells on $\mathrm{d} 3 \mathrm{or} \mathrm{d} 7$ post-tumour injection. Tumours were harvested for flow cytometric analysis at d27-31 post-tumour injection. (A) Tumour growth curves (as pooled and individual mice) and tumour weights; $n=34-35$, tumour size: two-way ANOVA with Bonferroni's post-test, tumour weight: unpaired t-test. (B) Frequency of human $\mathrm{CD} 3+\mathrm{T}$ cells of total viable cells in tumours, number of human CD3+ $T$ cells per $m g$ of tumour and $C D 4+/ C D 8+$ ratio of $C D 3+; n=16-21$, unpaired t-test. (C) Frequencies of $T$ cell subsets as defined by $C D 45 R O$ and $C D 62 L$ expression by intratumoural CD4+ and CD8+ T cells; $n=6-14$, two-way ANOVA with Bonferroni's post-test. (D) Frequency of PD-1, CTLA-4 and LAG-3 expression by intratumoural $C D 4+$ and $C D 8+T$ cells; $n=5-12$. Data are pooled from 6 independent experiments (A), or at least 3 independent experiments (B-D). Data are pooled from in vivo delivery of 5 independent CAR-T cell preparations derived from 4 healthy donors. Data represented as mean $\pm \mathrm{SEM}$; * $p \leq 0.05, * \star p \leq 0.01, * \star \star \star p \leq 0.0001$.

\section{Supplementary Files}

This is a list of supplementary files associated with this preprint. Click to download.

- Supplementarylnformation.docx

- ReportingExperimentalDesign.docx 
- Video1aCARTtransmigration.mp4

- Video1bCARTadhesion.mp4

- Video2aMDAvsUTCD3.mp4

- Video2bMDAvsCART.mp4 